University of Nebraska - Lincoln

DigitalCommons@University of Nebraska - Lincoln

USDA Wildlife Services - Staff Publications

U.S. Department of Agriculture: Animal and Plant Health Inspection Service

2018

Clinostomum poteae n. sp. (Digenea: Clinostomidae), in the trachea of a double-crested cormorant Phalacrocorax auritus Lesson, 1831 and molecular data linking the life-cycle stages of Clinostomum album Rosser, Alberson, Woodyard, Cunningham, Pote \& Griffin, 2017 in Mississippi, USA

Thomas G. Rosser

Mississippi State University, graham.rosser@msstate.edu

Wes A. Baumgartner

Mississippi State University

Neely R. Alberson

Mississippi State University

Travis W. Noto

Mississippi State University

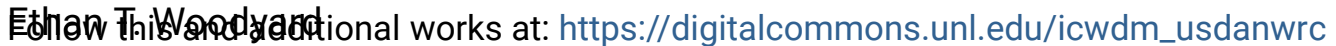
sissippi State University

Part of the Life Sciences Commons

See nextpage for additional authors

Rosser, Thomas G.; Baumgartner, Wes A.; Alberson, Neely R.; Noto, Travis W.; Woodyard, Ethan T.; King, D. Tommy; Wise, David J.; and Griffin, Matt J., "Clinostomum poteae n. sp. (Digenea: Clinostomidae), in the trachea of a double-crested cormorant Phalacrocorax auritus Lesson, 1831 and molecular data linking the life-cycle stages of Clinostomum album Rosser, Alberson, Woodyard, Cunningham, Pote \& Griffin, 2017 in Mississippi, USA" (2018). USDA Wildlife Services - Staff Publications. 2141.

https://digitalcommons.unl.edu/icwdm_usdanwrc/2141

This Article is brought to you for free and open access by the U.S. Department of Agriculture: Animal and Plant Health Inspection Service at DigitalCommons@University of Nebraska - Lincoln. It has been accepted for inclusion in USDA Wildlife Services - Staff Publications by an authorized administrator of DigitalCommons@University of Nebraska - Lincoln. 


\section{Authors}

Thomas G. Rosser, Wes A. Baumgartner, Neely R. Alberson, Travis W. Noto, Ethan T. Woodyard, D. Tommy King, David J. Wise, and Matt J. Griffin 


\title{
Clinostomum poteae n. sp. (Digenea: Clinostomidae), in the trachea of a double-crested cormorant Phalacrocorax auritus Lesson, 1831 and molecular data linking the life- cycle stages of Clinostomum album Rosser, Alberson, Woodyard, Cunningham, Pote \& Griffin, 2017 in Mississippi, USA
}

\author{
Thomas G. Rosser - Wes A. Baumgartner - Neely R. Alberson - Travis W. Noto \\ Ethan T. Woodyard $\cdot$ D. Tommy King $\cdot$ David J. Wise $\cdot$ Matt J. Griffin
}

Received: 9 March 2018/Accepted: 13 May 2018/Published online: 31 May 2018

(C) Springer Science+Business Media B.V., part of Springer Nature 2018

\begin{abstract}
Clinostomum spp. (Digenea: Clinostomidae) are a group of trematodes commonly found in the buccal cavity and oesophagus of a variety of piscivorous birds. The metacercariae, colloquially known as "yellow grubs," have been reported from a diverse group of freshwater fishes worldwide. In the catfish farming region of the southeastern USA, piscivorous
\end{abstract}

This article was registered in the Official Register of Zoological Nomenclature (ZooBank) as 508BCBDB-24C74ADC-8CBC-7B2089FD3B83. This article was published as an Online First article on the online publication date shown on this page. The article should be cited by using the doi number. This is the version of record.

This article is part of the Topical Collection Digenea.

Electronic supplementary material The online version of this article (https://doi.org/10.1007/s11230-018-9801-5) contains supplementary material, which is available to authorized users.

T. G. Rosser $(\varangle) \cdot$ N. R. Alberson

T. W. Noto - E. T. Woodyard

Department of Basic Sciences, College of Veterinary

Medicine, Mississippi State University, Mississippi State,

MS 39762, USA

e-mail: graham.rosser@msstate.edu

W. A. Baumgartner · M. J. Griffin

Department of Pathobiology and Population Medicine,

College of Veterinary Medicine, Mississippi State

University, Mississippi State, MS 39762, USA birds present a continuous challenge for aquaculturists in the form of fish depredation and the introduction of trematodes into these static, earthen pond systems. Clinostomum spp. are commonly encountered in farmraised catfish. While generally considered pests of minimal importance, heavy infections can result in unmarketable fillets. Of the piscivorous birds that frequent catfish aquaculture operations in the southeastern US, the double-crested cormorant (Phalacrocorax auritus Lesson) is one of the most damaging, although reports of Clinostomum spp. from P. auritus are limited. In this study, adult trematodes morphologically consistent with Clinostomum sp. were found in the trachea of a double-crested cormorant captured in Lowndes Co., Mississippi, USA. These specimens differed from other recognised Clinostomum spp. in several key morphological characters. Moreover, sequence data of mitochondrial cytochrome $c$ oxidase subunit 1 gene $(\operatorname{cox} 1)$, nicotinamide adenine

D. Tommy King

Mississippi Field Station, National Wildlife Research Center, Wildlife Services, United States Department of Agriculture, Mississippi State, MS 39762, USA

\section{J. Wise · M. J. Griffin}

Thad Cochran National Warmwater Aquaculture Center, Delta Research and Extension Center, Mississippi State University, Stoneville, MS 38776, USA 
dinucleotide dehydrogenase subunit 1 gene (nad 1 ) and ribosomal internal transcribed spacer(ITS) regions did not match any known Clinostomum sp. for which sequence data are available. While genetically similar to C. marginatum and C. album Rosser, Alberson, Woodyard, Cunningham, Pote \& Griffin, 2017 reported from the great egret Ardea alba L. in Mississippi, these adult clinostomids were larger in size and limited to the trachea, whereas both $C$. marginatum Rudolphi, 1819 and C. album are found in the oral cavity and esophagus. Given these distinct morphological and molecular characters we propose a new member of the genus, known hereafter as Clinostomum poteae n. sp. Additionally, larval stages in the life-cycle of C. album are morphologically and molecularly identified for the first time from ramshorn snails Planorbella trivolvis Say and fathead minnows Pimephales promelas Rafinesque.

\section{Introduction}

The Clinostomidae Lühe, 1901 is a diverse family of trematodes found primarily in the buccal cavity and oesophagus of birds, reptiles, and mammals (Ukoli et al., 1966). Of the clinostomids, Clinostomum spp. Leidy, 1856 have been well documented in the literature and are recognised globally as parasites of economic and ecologic importance in freshwater fish and amphibians. The metacercaria stage is often referred to by aquaculturists, fish health professionals and parasitologists by the colloquial name "yellow grub". Freshwater snails, usually of the family Planorbidae Rafinesque, serve as the first intermediate host (Krull, 1934; Pinto et al., 2015).

Currently, experimental life-cycle studies using natural definitive hosts are rarely performed as they are labor intensive and in many cases logistically unfeasible due to availability of hosts, regulatory hurdles and other interfering factors. In the absence of experimental challenges, putative life histories and the other aspects of parasite ecology can be determined by linking molecular sequence data obtained from morphologically ambiguous larval stages to gene sequences collected from adult specimens identified by morphologically distinct characters (Criscione et al., 2005). Studies investigating the global and regional diversity of Clinostomum species have demonstrated an unexpected number of putative species identified by molecular and phylogenetic analyses of nuclear and mitochondrial genes (namely the internal transcribed spacer regions and cytochrome $c$ oxidase subunit 1 gene) (Locke et al., 2015; PérezPonce de León et al., 2016). In North America, six distinct Clinostomum spp. are recognised based on discrete morphological characters, all of which have molecular sequence data available for reference (Bravo-Hollis, 1947; Hutton \& Sogandares-Bernal, 1960; Sereno-Uribe et al., 2013; Locke et al., 2015; Rosser et al., 2017; Briosio-Anguilar et al., 2018). At least nine additional Clinostomum spp. are proposed, based solely on mitochondrial cytochrome $c$ oxidase subunit 1 gene (cox1) and ribosomal internal transcribed spacer regions (ITS) sequences obtained from larval (Locke et al., 2015) and some adult stages (Pérez-Ponce de León et al., 2016), although corresponding morphological data for these putative species are limited. Further efforts to elucidate the species boundaries within the genus Clinostomum should require detailed morphometric analysis, in combination with molecular analyses of multiple gene targets, and when available, the inclusion of ecological data. Ecological data should include primary host range, tissue tropism, geographical locality and other aspects as recommended by Blasco-Costa et al. (2016).

In the southeastern USA, production of channel Ictalurus punctatus Rafinesque and hybrid catfish (우 channel catfish $\mathrm{x} \hat{\jmath}$ blue catfish Ictalurus furcatus Valenciennes) is hindered by losses due to depredation by piscivorous birds and the trematodes they introduce into these systems. Double-crested cormorants Phalacrocorax auritus Lesson are one of the most damaging on account of their high prevalence and consumption rates (Glahn \& King, 2004). A recent parasitological survey of cormorants from the catfish farming region of northwestern Mississippi revealed a diversity of trematodes (O'Hear et al., 2014), several of which have since been identified as parasites of catfish (Griffin et al., 2012; Rosser et al., 2016a, b). Clinostomum spp. have not been reported from double-crested cormorants in Mississippi but have been reported in the great egret Ardea alba L. (see Rosser et al., 2017) and other ardeid hosts foraging on or near catfish operations (Overstreet \& Curran 2004).

Clinostomum marginatum Rudolphi, 1819 is reported from channel catfish, but infections are considered of limited importance as no significant 
pathological changes have been associated with infections and their impacts on production are negligible (Hawke \& Khoo, 2004). However, in heavy infections, stunted growth may occur and the presence of numerous metacercariae in the musculature of the fish may result in rejection at processing (Hawke \& Khoo, 2004). In addition to $C$. marginatum, great egrets in Mississippi are also infected with a second species, Clinostomum album Rosser, Alberson, Woodyard, Cunningham, Pote \& Griffin, 2017. In Florida, USA, Hutton \& Sogandares-Bernal (1960) noted Clinostomum attenuatum Cort, 1913 from the trachea of the Florida cormorant Phalacrocorax auritus floridanus Audubon. Similarly, Threlfall (1982) reports $C$. marginatum from the trachea and lungs of double-crested cormorant, P. auritus, in Florida, USA. A Clinostomum sp., reported as Clinostomum complanatum (Rudolphi, 1814), was also reported from the oral cavity and oesophagus of the Neotropic cormorant Phalacrocorax brasilianus Gmelin, the freshwater mollusc Biomphalaria peregrina d'Orbigny, four siluriform and one characiform fish in Brazil (Dias et al., 2003). However, recent morphological and molecular studies suggest the species designated as $C$. complanatum in the Americas may be misclassified (Caffara et al., 2011; Sereno-Uribe et al., 2013). Retrospective examination of specimens identified as C. complanatum from Central America were actually considered $C$. marginatum or the more recently described Clinostomum tataxumui SerenoUribe, Pinacho-Pinacho, García-Varela \& PérezPonce de León, 2013. The current literature suggests C. complanatum is not presently found in the New World, but further morphological and molecular studies are needed to verify these claims.

Herein we present a Clinostomum sp. described from the trachea of a single double-crested cormorant. Morphological and molecular data suggest this is a previously uncharacterised species, hereafter known as Clinostomum poteae $\mathrm{n}$. sp. Additionally, we provide molecular data linking the larval stages of C. album in the snail and fish host. Histopathological characterisation of infections in the snail host, and novel molecular data of the nicotinamide adenine dinucleotide dehydrogenase subunit 1 gene (nad1) for three Clinostomum species are discussed.

\section{Materials and methods}

\section{Bird trapping and necropsy}

In September 2016, a single double-crested cormorant Phalacrocorax auritus, collected from Lowndes Co., Mississippi, USA, was euthanised using $\mathrm{CO}_{2}$ and examined for helminth infections. The entire gastrointestinal tract was removed before being separated into four compartments: oesophagus, proventriculus and gizzard, and intestine (beginning posterior to the gizzard and terminating at the cloaca). The trachea and lower respiratory tract were also removed. All organs were opened longitudinally and examined grossly for the presence of helminths. The mucosal lining of the partitioned sections of the gastrointestinal tract were scraped manually and the contents washed with dechlorinated water into a $38-\mu \mathrm{m}$ aperture brass sieve. The screened contents were rinsed into a container with $0.09 \%$ saline and the contents were examined in a lined Petri dish with the aid of a dissecting stereomicroscope (Olympus SZ60, Olympus Optical Co. Ltd., Tokyo, Japan). Adult helminths were collected and placed in $0.09 \%$ saline. Clinostomum sp. adults found attached to the lining of the trachea were gently detached with featherweight forceps (BioQuip Products, Rancho Dominquez, California, USA) and placed in $0.09 \%$ saline. All helminths were relaxed in nearly boiling saline and fixed in $70 \%$ ethanol. Adult trematodes morphologically consistent with Clinostomum sp. were limited to the trachea and are the focus of this work.

\section{Snail host and cercariae collection}

Ramshorn snails Planorbella trivolvis Say were collected (September 2016) from vegetation along the banks of a catfish production pond in Leflore County, Mississippi, USA, using a 1.5-mm mesh aquatic dip net. Snails were placed into 18.91 buckets containing $c .101$ of pond water and transported to the Thad Cochran National Warmwater Aquaculture Center. Snails were rinsed with well water, placed individually into plastic dilution vials (Fisher Scientific, Pittsburgh, Pennsylvania, USA) and covered with c. $10 \mathrm{ml}$ of autoclaved spring water (Ozarka ${ }^{\circledR}$, Wilkes Barre, Pennsylvania, USA). Every 24 hours the water column in each dilution vial was examined using a dissecting microscope (Olympus SZ60, Olympus Optical Co. Ltd., Tokyo, Japan) for cercariae. When cercariae were observed, a 1-ml aliquot of cercaria 
laden water was frozen at $-20^{\circ} \mathrm{C}$ for molecular analysis from each infected snail.

\section{Metacercariae collection}

As part of a routine diagnostic investigation of fish health in a commercial catfish production pond in Lowndes County, Mississippi, USA, a single fathead minnow $(6.6 \mathrm{~cm})$ Pimephales promelas Rafinesque was examined in March 2017. Two encysted Clinostomum sp. metacercariae were collected from the coelomic cavity, excysted manually with metal pins, relaxed in nearly boiling $0.09 \%$ saline, and fixed in $70 \%$ ethanol for morphological and molecular analysis. An ethanol-archived specimen identified as $C$. marginatum from a blue gill Lepomis macrochirus Rafinesque was also trimmed for molecular analysis and included in this study.

\section{Trematode staining and morphological analysis}

A subsample $(\mathrm{n}=10)$ of Clinostomum specimens from the trachea of the double-crested cormorant was transitioned from $70 \%$ ethanol to distilled water through a decreasing gradient of 1 hour ethanol washes $(50 \%, 30 \%$ and $10 \%)$. Specimens were stained using Van Cleave's hematoxylin and mounted in Canada balsam. For a single specimen the entire worm was cleared in lactophenol and examined for body armature. A single specimen had a small section of the posterior extremity, not including reproductive organs, excised with a sterile scalpel blade and placed into a $1.5 \mathrm{ml}$ tube for molecular analysis. This hologenophore was stained with Mayer's carmalum and mounted as described above.

Cercariae were studied live and vitally stained with $0.5 \%$ Jensen's neutral red [ 1 drop $(c .30 \mu \mathrm{l})$ of neutral red per $50 \mathrm{ml}$ of cercariae in autoclaved spring water]. A portion were stained with Semichon's acetocarmine, destained in acidic ethanol, dehydrated in an increasing ethanol series, cleared in Hemo-De and mounted in Canada balsam as museum vouchers. Rediae were teased from the hepatopancreas of a single infected snail using insect pins, killed with nearboiling $0.09 \%$ saline and fixed in $70 \%$ ethanol. Saline wet mounts of rediae were examined for morphological characterisation. Voucher specimens of ethanol fixed rediae and cercariae were stained in Semichon's acetocarmine, destained in acidic ethanol, dehydrated in an increasing series of ethanol washes, cleared in Hemo-De, and mounted in Canada balsam. A second infected snail was relaxed in water with menthol crystals, briefly submerged in near boiling water, the body was gently removed with feather weight forceps, and fixed in Railliet-Henry's fixative (6 g sodium chloride dissolved in $930 \mathrm{ml}$ distilled water, $50 \mathrm{ml}$ formaldehyde $(37 \%, \mathrm{w} / \mathrm{v})$, and $20 \mathrm{ml}$ glacial acetic acid) for histopathological examination.

Type- and voucher specimens were submitted to the Smithsonian Institution, National Museum of Natural History, Washington, DC, USA. Line drawings were made using a camera lucida and digitised using Adobe Illustrator CC 2017 (Adobe, San Jose, California, USA). Morphological characters are reported in micrometres and measurements are presented as the range, with mean ( \pm standard deviation where applicable) in parentheses.

\section{Fish experimental challenges}

Clinostomid cercariae collected from infected snails were pooled into a 500-ml beaker, the water was gently agitated with a magnetic stir bar, and the average number of cercariae per milliliter was determined from ten $0.1 \mathrm{ml}$ aliquots according to previously established protocols (Griffin et al., 2012, 2014; Rosser et al., 2016b; Alberson et al., 2017). Channel catfish fingerlings $(c .2-4 \mathrm{~cm})$ reared indoors for infectious disease research at the Thad Cochran National Warmwater Aquaculture Center in Stoneville, MS, were used in infectivity studies. Fish were placed in 1 gallon containers ( 7 containers, 3 fish/container) containing 3.81 of water with supplemental aeration and exposed to either $600(n=9)$ or 1,200 $(n=9)$ clinostomid cercariae per fish. One group of three fish were not exposed to cercariae and served as negative controls. Exposures lasted for four hours. Fish from each exposure group were placed into discrete 115-1 aquaria, containing $c .80$ liters of well water $\left(c .26-27^{\circ} \mathrm{C}\right)$ supplied at $1.9 \mathrm{l} / \mathrm{min}$, with supplemental aeration. Fish were fed ad libitum and monitored twice daily for morbidity and mortality. Once weekly, fish were netted and examined grossly for the presence of metacercariae. Fish were sacrificed at 60 days post-exposure, examined grossly for the presence of metacercariae and a subsample of fish from the 1,200 cercariae/fish exposure group $(n=8)$ were submitted for histopathological analysis.

\section{Histopathological analysis}

The single snail used in histopathalogical analysis was kept in Railliet-Henry's fixative for at least 24 hours, 
hemisectioned, and embedded in paraffin wax for standard light microscopy slide preparation. Sections were stained with hematoxylin and eosin (HE) or periodic acid-Schiff methods for examination.

Eight channel catfish fingerlings (c.5 cm long) exposed to 1,200 cercariae/fish were euthanised 60 days post-infection with an overdose of tricaine methanesulfonate, abdomens opened by incision and fixed in $10 \%$ neutral buffered formalin for a minimum of 72 hours. Fish were decalcified in Kristensen's solution for 12 hours, soaked in sodium bicarbonate rich tap water to neutralise tissue $\mathrm{pH}$, and fish were trimmed in c.3-mm cross-sections starting rostrally and moving caudally, with small adjustments to thickness to ensure all major organs were sampled. Tissues were processed routinely, embedded in paraffin, sectioned at approximately $4 \mu \mathrm{m}$, stained with hematoxylin and eosin (HE), and examined using light microscopy.

\section{Molecular analysis}

Genomic DNA was extracted from three whole adult Clinostomum specimens from the trachea of the cormorant and the section of the hologenophore using the DNeasy Blood and Tissue Kit (Qiagen, Valencia, California, USA). Fragments $(c .500$ bp) of the cytochrome $c$ oxidase subunit 1 ( $\operatorname{cox} 1)$ and mitochondrial nicotinamide adenine dinucleotide dehydrogenase subunit 1 (nad1) genes were amplified by PCR and sequenced from all specimens. An c.4,800-bp region of ribosomal DNA spanning the $18 \mathrm{~S}$ rRNA gene, internal transcribed spacer (ITS) 1 region, 5.8S rRNA gene, ITS2 region, and partial 28S rRNA gene was sequenced from a single whole adult specimen, while only the ITS1, 5.8S rRNA gene, and ITS2 region was sequenced from the remaining three adult specimens. Primers used in amplifying each region are listed in Supplementary Table 1. Briefly, each $20-\mu 1$ reaction consisted of $7 \mu \mathrm{l}$ of nuclease-free water, $10 \mu \mathrm{l}$ of Phusion Green Hot Start II High-Fidelity PCR Master Mix, $10 \mu \mathrm{M}$ of each primer, and $1 \mu \mathrm{l}$ of genomic DNA $(c .10 \mathrm{ng} / \mu \mathrm{l})$. Cycling parameters for the 1F/5R, BD1/BD2, LSU5/1500R, and NDJ11/NDJ2a primer sets were $98^{\circ} \mathrm{C}$ for $3 \mathrm{~min}, 39$ cycles at $98^{\circ} \mathrm{C}$ for $10 \mathrm{~s}, 48^{\circ} \mathrm{C}$ for $30 \mathrm{~s}$, and $72{ }^{\circ} \mathrm{C}$ for $1 \mathrm{~min}$, and a final extension at $72^{\circ} \mathrm{C}$ for $10 \mathrm{~min}$. The Barker3/Barker4 primer set differed from the others by an annealing temperature of $53^{\circ} \mathrm{C}$. Similarly, the Diplo1795F/ Diplo2549R, Diplo2617F/Diplo3170R, 28S3431F/
28S4779R, and 28S4759F/28S5699R primer sets differed by an annealing temperature of $58^{\circ} \mathrm{C}$.

Frozen 1-ml aliquots of water containing Clinostomum sp. cercariae released by $P$. trivolvis were thawed, contents were pelleted by centrifugation $(10,000 \times \mathrm{g}$ for $10 \mathrm{~min})$, and gDNA was extracted using the DNeasy PowerSoil Kit (Qiagen Inc.) according to the manufacturer's protocol. Total gDNA from the portion of tissue excised from the each metacercaria was extracted as described for the adult Clinostomum sp. For all cercariae and metacercariae gDNA extracts, three regions were amplified as described previously using the BD1/BD2 primers for the ribosomal ITS regions, cox1_schist5'/acox650r primers for the $\operatorname{cox} 1$ gene, and NDJ11/NDJ2a primers for the nad 1 gene. Additionally, the nad 1 gene was amplified from archived gDNA of an adult of Clinostomum marginatum from a great egret $(\mathrm{n}=1)$ (Rosser et al., 2017), metacercaria of $C$. marginatum from an inland silverside ( $\mathrm{n}=1$ ) (Rosser et al., 2016b), and an adult of Clinostomum album collected from a great egret $(n=1)$ (Rosser et al., 2017).

PCR products were electrophoresed through $0.8 \%$ agarose gels in the presence of ethidium bromide $(0.5 \mu \mathrm{g} /$ $\mathrm{ml}$ ) and visualised under ultraviolet light. Each gel was run with a concurrent molecular weight ladder (HyperLadder ${ }^{\mathrm{TM}} 50 \mathrm{bp}$, Bioline, London, UK) to confirm presence of appropriate sized bands. Amplicons were excised and purified for sequencing using the QIAquick Gel Extraction Kit (Qiagen Inc.). Products were commercially sequenced bidirectionally with the forward and reverse primer used to generate each representative amplicon (Eurofins MWG Operon LLC, Huntsville, Alabama, USA). Electropherograms for the ribosomal and mitochondrial regions were aligned and annotated using Geneious $^{\circledR}$ 10.1.3 (Biomatters Ltd., Auckland, New Zealand). The contiguous rRNA, cox 1 , and nad 1 gene sequences were compared to other Clinostomum species available in the National Center for Biotechnology Information non-redundant nucleotide database (NCBI nr/nt) by a BLASTN search (Altschul et al., 1990).

\section{Phylogenetic analyses}

Archived sequences of representative species of the family Clinostomidae Lühe, 1901, were downloaded from the NCBI nr/nt database and in some cases obtained from supplementary files from original works (i.e. Locke et al., 2015) (Supplementary Table 2). Downloaded sequences were limited to specimens 
with data available for both the ITS regions and cox 1 gene, Additionally, two members of the Diplostomidae Poirier, 1886 (Alaria mustelae Bosma, 1931 and Diplostomum baeri Dubois, 1937) were included in the alignments as outgroups. For the ribosomal region dataset, the ITS1, 5.8S rRNA gene, and ITS2 region were extracted using ITSx v. 1.0.11 (Bengtsson-Palme et al., 2013). The cox 1 and extracted ITS1, 5.8S rRNA, and ITS2 regions were aligned with MAFFT 7.222 in Geneious ${ }^{\circledR}$ 10.1.3 (Katoh et al., 2002; Katoh \& Standley, 2013). Positions in each alignment containing at least one gap were eliminated and the regions were concatenated for a final alignment containing 1,127 positions. The Bayesian Information Criterion was used to select the nucleotide substation models that best described the data for each region (Nei \& Kumar, 2000; Kumar et al., 2016): cox 1 codon position 1 (TN93 + I; 164 positions), cox 1 codon position 2 (HKY; 164 positions), cox 1 codon position 3 (TN93 + G; 164 positions), ITS1 region (K2 + G; 399 positions), $5.8 \mathrm{~S}$ rRNA gene (JC; 157 positions), and ITS2 region (JC $+\mathrm{G} ; 70$ positions). Bayesian inference analysis was performed in MrBayes 3.2.6 using Markov chain Monte Carlo searches of two simultaneous runs of four chains with sampling of every 100th tree until convergence, when the value of the standard deviation of split frequencies was $<0.01$. At this point the first $25 \%$ were discarded as 'burn-in' and posterior probabilities were calculated from the remaining trees. Maximum likelihood analysis was performed using IQ-Tree (Nguyen et al., 2015) on the IQ-Tree web server (Trifinopoulos et al., 2016) with the concatenated alignment and partition scheme described previously. Branch support was tested using ultrafast bootstrap support (Minh et al., 2013) with 1,000 pseudoreplicates. Dendrograms were viewed in FigTree 1.4.2 (Rambaut, 2014) and annotated in Adobe Illustrator CC 2017 (Adobe, San Jose, California, USA). Pairwise distances based on the cox 1 sequences used in the alignment for phylogenetic analysis and nad 1 sequences were calculated using MEGA7 (Kumar et al., 2016).

\section{Family Clinostomidae Lühe, 1901 Genus Clinostomum Leidy, 1856}

\section{Clinostomum poteae $\mathbf{n}$. sp.}

Type-host: Phalacrocorax auritus (Lesson) (Aves: Phalacrocoracidae), double-crested cormorant.
Type-locality: Lowndes County, Mississippi, USA.

Site in host: Trachea.

Type-material: Holotype USNM 1488288; 3 paratypes USNM 1488289-1488291; 1 hologenophore USNM 1488292.

Prevalence and intensity of infection: 1 of 1 P. auritus; 22 worms.

Representative DNA sequences: GenBank MH282567-MH282570 (ribosomal regions); MH282550-MH282553 (cox1 gene); MH282520MH282522 (nad1 gene).

Zoobank registration: To comply with the regulations set out in article 8.5 of the amended 2012 version of the International Code of Zoological Nomenclature (ICZN, 2012), details of the new species have been submitted to ZooBank. The Life Science Identifier (LSID). The LSID for Clinostomum poteae $\mathrm{n}$. sp. is urn:lsid:zoobank.org:act:25DA863A-F83C-4540B95F-9299B24835CA.

Etymology: The species epithet is reference to and in memory of parasitologist Dr Linda Marie Wayland Pote in recognition of her contributions to the field of aquatic animal and avian parasitology, and her enthusiasm for training a new generation of parasitologists.

Description (Figs. 1, 2)

[Based on 10 ovigerous adults, Van Cleave's hematoxylin stained and mounted in Canada balsam, see Table 1.] Body, aspinose, dorso-ventrally flattened, linguiform, widest at level of gonads, slightly constricted at ventral sucker level, $7,256-9,144 \times 1,628-2,210(8,178 \times 1,930)$; body length to body width ratio $3.8-4.7$ (4.2). Oral collarlike fold typical of Clinostomum spp., $652-910 \times 940-1,153(757 \times 1,064)$ surrounding oral sucker. Oral sucker spherical, 311-365 × 337-400 $(331 \times 370)$. Pharynx not observed, branching of intestinal caeca occurs just posterior to oral collar. Paired intestinal caeca laterally extend almost entire length of body with broad diverticular foldings beginning at level of posterior border of ventral sucker. Ventral sucker large, $797-922 \times 834-978(875 \times 909)$, located in lower to middle portion of anterior third of body. Distance between oral and ventral suckers 669-936 (769).

Testes 2, tandem, located in upper third of hindbody. Anterior testis variably lobed, $441-665 \times 594-928(550 \times 792)$. Posterior testis 
A

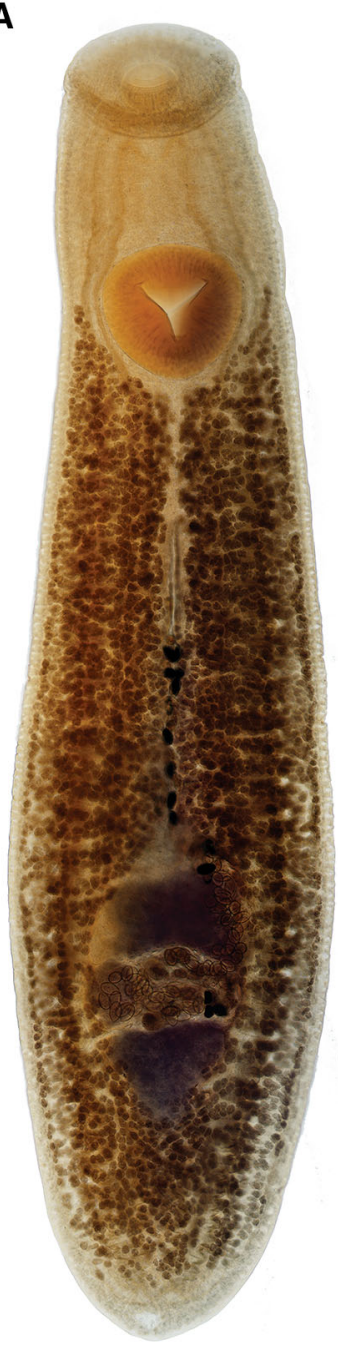

B

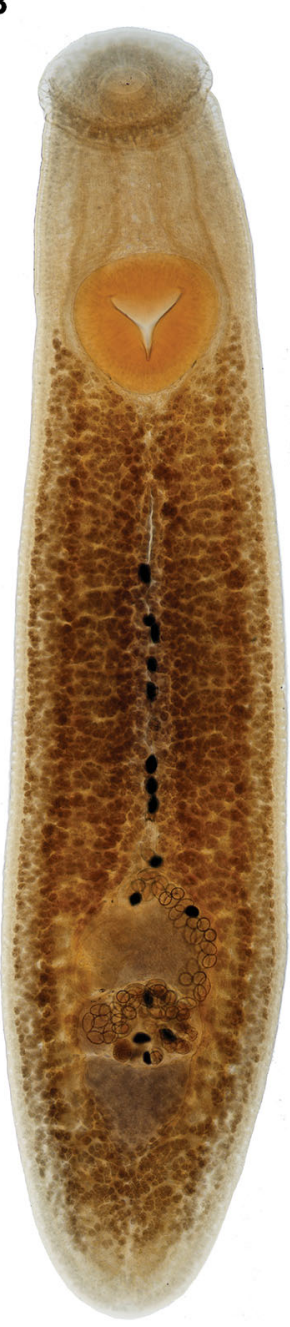

C

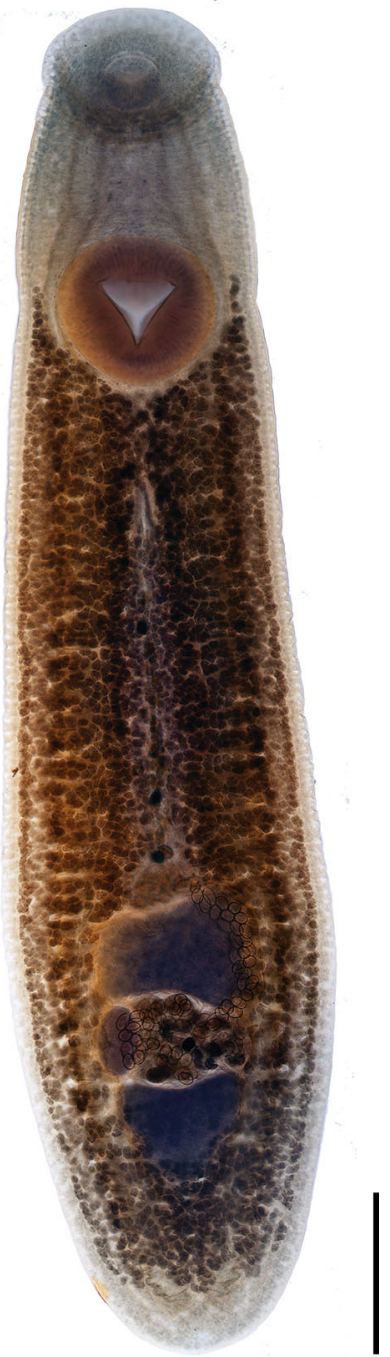

Fig. 1 Photomicrographs of Van Cleave's hematoxylin-stained Clinostomum poteae n. sp. from Phalacrocorax auritus collected in Lowndes County, Mississippi, USA. A, Holotype; B-C, Paratypes. Scale-bar: $1 \mathrm{~mm}$

triangular, lobed, 463-699 × 528-799 $(601 \times 715)$. Distance between testes 472-590 (524). Cirrus-sac, ovoid, 503-662 × 294-445 $(553 \times 382)$, located at level of and overlapping right margin of anterior testis.

Ovary dextral, intertesticular, ovoid, 328-428 × 225-307 (396 × 268). Oötype complex, intertesticular, located at midline of body. Mehlis' gland prominent, finer details of Laurer's canal obscured by presence of eggs. Uterine duct intracaecal, extending anteriorly around left margin of anterior testis before opening into uterine sac. Uterine sac tubular, extends anteriorly in midline of body to level of posterior margin of ventral sucker. Genital pore opening into genital atrium near midline or right margin of the body at level of anterior testis. Anterior limits of vitelline fields at midpoint of ventral sucker, posterior limits at posterior end of caeca. Eggs yellowish, operculate, 105-119 × 63-75 $(112 \times 71)$.

\section{Remarks}

Clinostomum poteae n. sp. is morphologically consistent with other members of the genus and the ranges for many morphological characters overlap with other Clinostomum spp. from the Americas (Table 1). Clinostomum intermedialis Lamont, 1920 described 


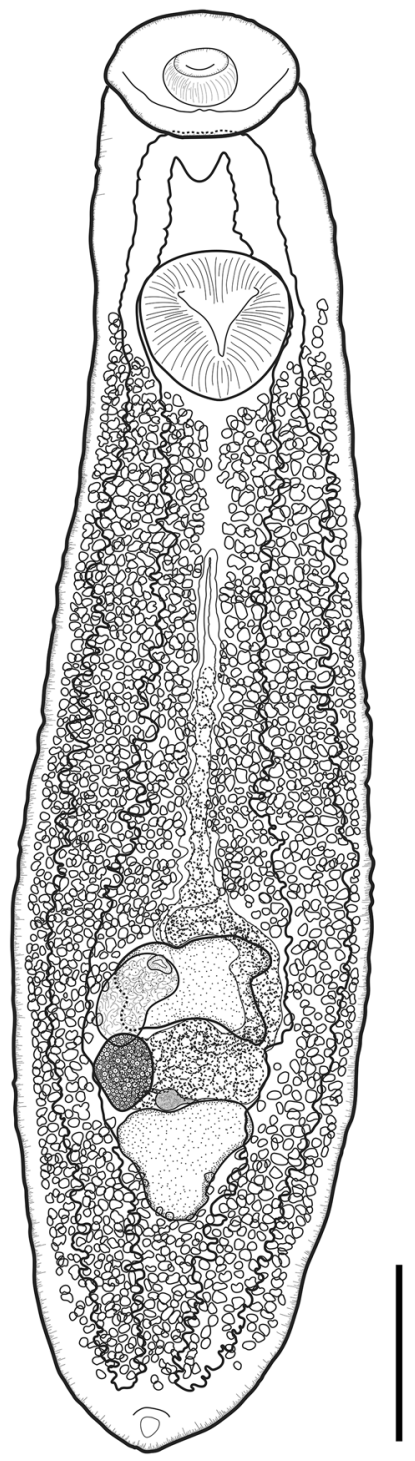

Fig. 2 Line drawing of the holotype of Clinostomum poteae $\mathrm{n}$. sp. from Phalacrocorax auritus collected in Lowndes County, Mississippi, USA. Scale-bar: $1 \mathrm{~mm}$

from Phalacrocorax vigua Vieillot differs from $C$. poteae $\mathrm{n} . \mathrm{sp}$. in the placement of the anterior testis and its size. The anterior testis of $C$. intermedialis is distinctly ovoid in mature specimens and located in the left margin of the body compared to the typically lobed anterior testis of other Clinostomum spp. and placement in the midline of the body. Based on the most recent description by Bravo-Hollis (1947) both testes of $C$. intermedialis are considerably larger in size compared to the other Clinostomum spp. from the Americas except for Clinostomum heluans Braun,
1899 in which the gonads are located posteriorly in the body. Lunaschi \& Drago (2009) considered C. intermedialis a member of the genus Clinostomatopsis Dollfus, 1932 based on the placement of the genital pore. Although similar in morphology to C. attenuatum studied by Hutton \& Sogandares-Bernal (1960) from the trachea of cormorants, morphological variations exist between C. attenuatum and C. poteae n. sp. Hutton $\&$ Sogandares-Bernal (1960) provided measurements for the seven adult specimens they encountered. Using these data, additional morphometric parameters used in previous studies of Clinostomum spp. were evaluated. These include the ratios body length/body width, oral sucker width/body width, ventral sucker width/oral sucker width, ventral sucker width/body width, anterior testis width/anterior testis length, posterior testis width/posterior testis length, and ovary width/ovary length (Table 1). Clinostomum attenuatum is notably wider than $C$. poteae n. sp. in regard to body width and has a smaller ratio of body length to body width, with $C$. poteae being consistently longer. The testes size for $C$. attenuatum compared with $C$. poteae $\mathrm{n}$. sp. are notably wider, although ranges for length and width slightly overlap. Hutton \& Sogandares-Bernal (1960) noted the testes of $C$. attenuatum were crescent shape in most specimens with few being slightly lobed. This is in contrast to the distinctly lobed nature of the testes of $C$. poteae $\mathrm{n}$. sp., especially in regard to the anterior testis. Clinostomum marginatum has also been reported from the trachea of double-crested cormorants in Florida; however, the placement of the gonads and size of the ovary of $C$. poteae n. sp. differs from $C$. marginatum described from ardeid birds (Caffara et al., 2011; Rosser et al., 2017).

In addition to morphological variation, $C$. poteae $\mathrm{n}$. sp. is molecularly distinct from any Clinostomum sp. with cox 1 sequence data to date, including C. album, C. attenuatum, C. marginatum, and C. tataxumui, two of which have been reported from double-crested cormorants.

Clinostomum album Rosser, Alberson, Woodyard, Cunningham, Pote \& Griffin, 2017

First intermediate host: Planorbella trivolvis (Say) (Gastropoda: Planorbidae).

Second intermediate host: Fathead minnow Pimephales promelas (Rafinesque) (Cypriniformes: Cyprinidae).

Site in host: Hepatopancreas (ex P. trivolvis); coeolomic cavity (ex P. promelas). 


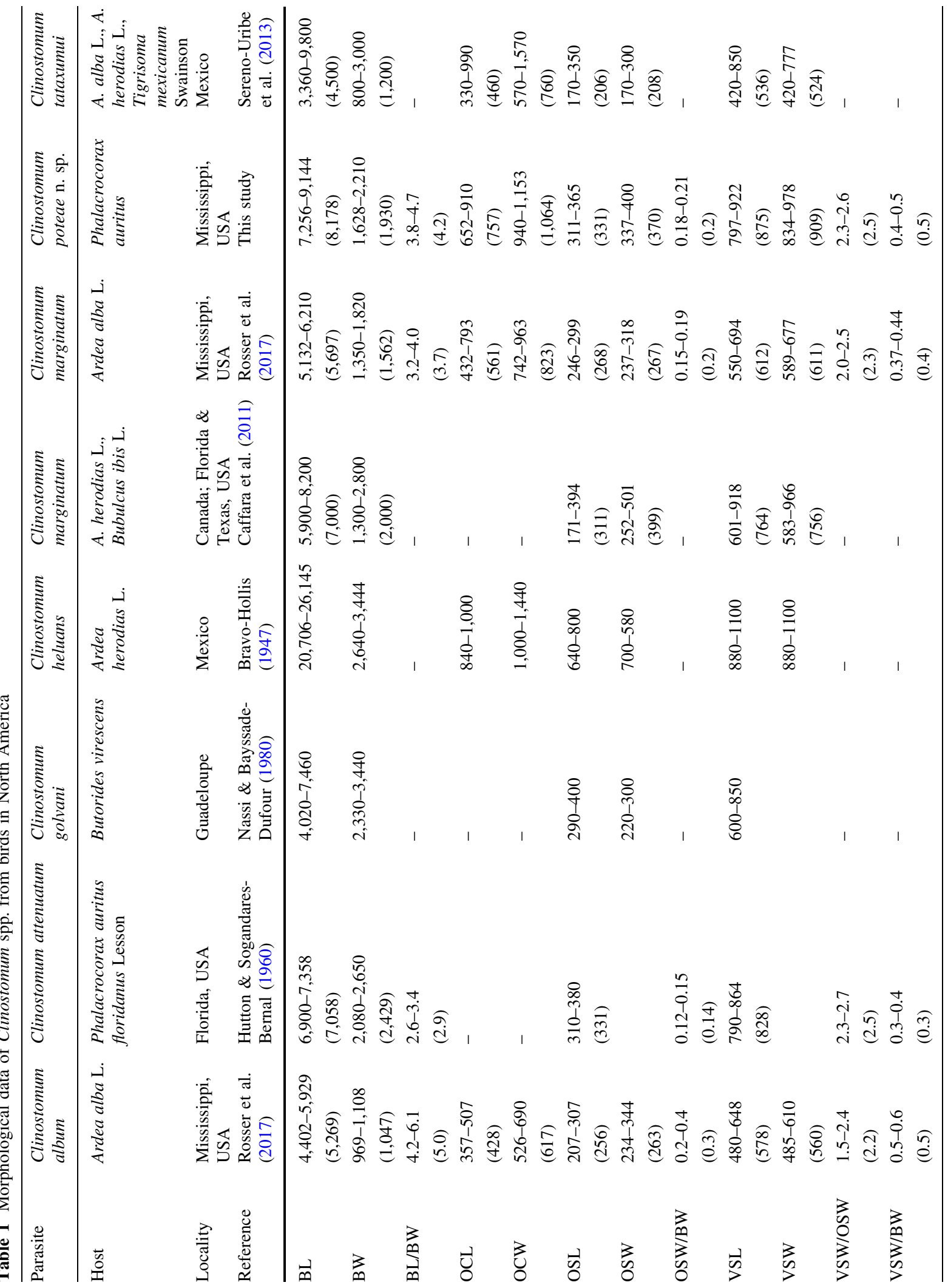




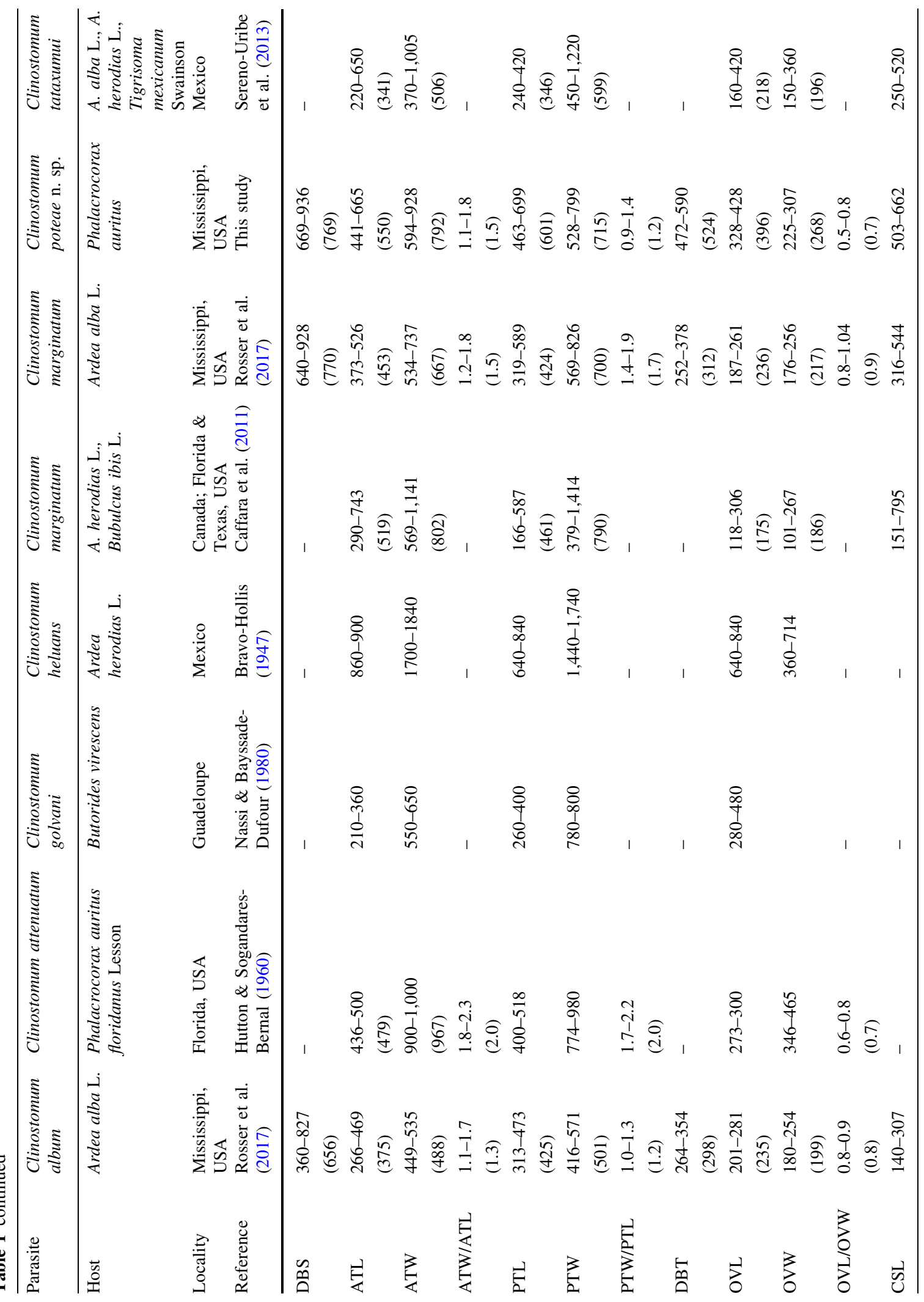




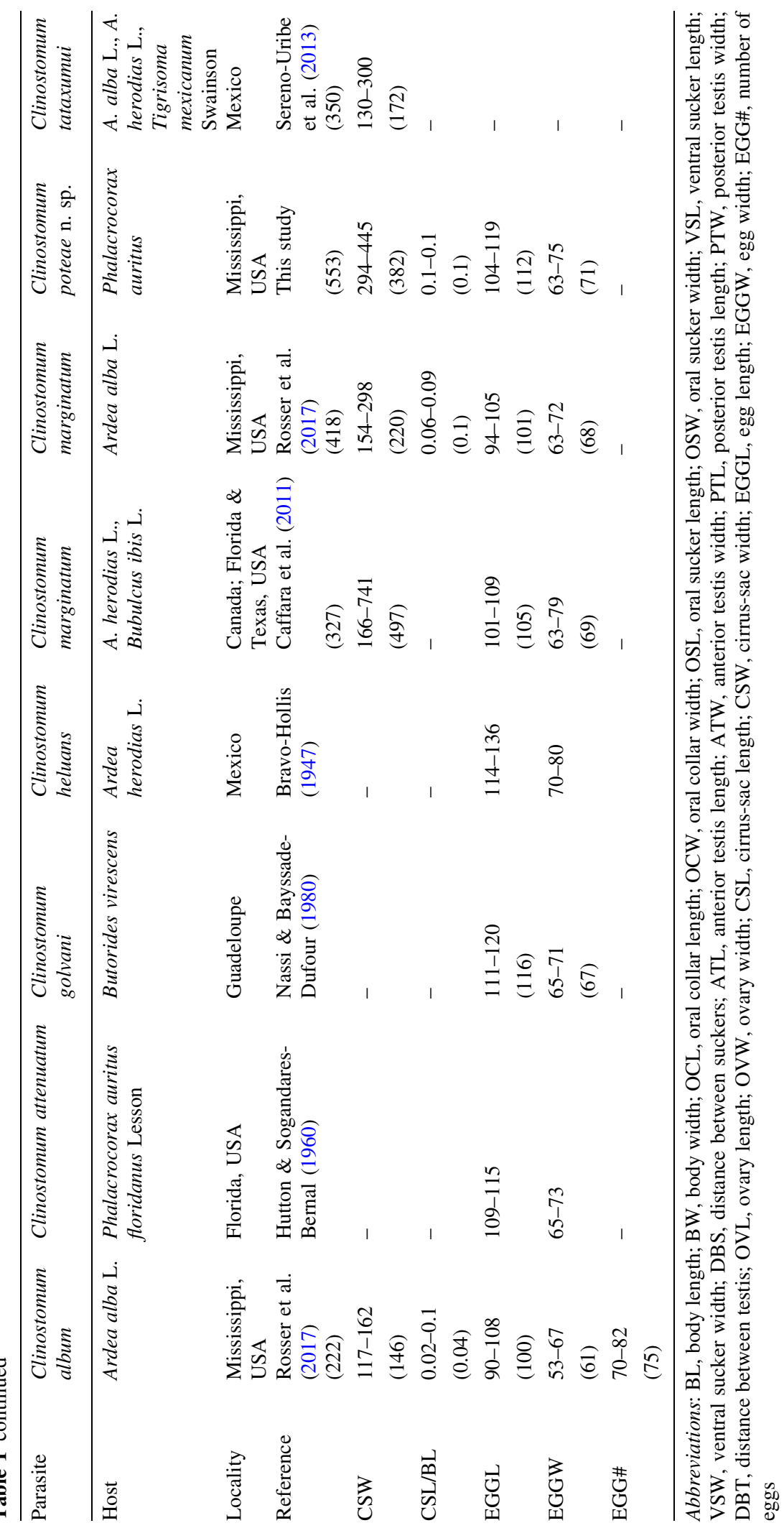


Localities: Catfish pond, Leflore County, Mississippi, USA (ex P. trivolvis); catfish pond, Lowndes County, Mississippi, USA (ex P. promelas).

Infection parameters: Prevalence $4.3 \%$ (in 10 out of 230 snails) (ex P. trivolvis); prevalence $100 \%$ (in 1 out of 1 fish) (ex P. promelas); intensity: 2 metacercariae (ex P. promelas).

Voucher material: 2 voucher slides of Semichon's acetocarmine-stained cercariae USNM 1488293-1488294, 3 voucher slides of Semichon's acetocarmine-stained rediae USNM 1488295-1488297, 2 voucher slides of hematoxylin and eosin stained rediae and cercariae in situ USNM 1488298-1488299, 1 metacercaria hologenophore USNM 1488300.

Representative DNA sequences: GenBank MH282556-MH282566 (ribosomal regions); MH282539-MH282549 (cox1 gene); MH282526MH282537 (nad1 gene).

Description (Figs. 3-6)

\section{Redia}

[Based on whole mounts of 34 heat killed and ethanolfixed rediae from a single snail host; see Supplementary Table 3.] Rediae yellow-tan in color, numerous in the hepatopancreas of $P$. trivolvis, globular to elongate, $271-819(455 \pm 111) \times 97-235(150 \pm 31)$ (Figs. 3A, B, 4C). Body constricted near anterior in some specimens, usually just posterior to pharynx. Pharynx muscular, subterminal, 30-57 $(47 \pm 8) \times$ $31-58(46 \pm 7)$. Anterior region of body spinose, with $7-8$ rows of transverse spines, extending to region at posterior margin of pharynx (Fig. 3C). Intestine tubular, elongate, 162-523 $(291 \pm 76) \times 28-59$ $(41 \pm 10)$, length representing $44-85(65 \pm 11) \%$ of body length. Germinal cells observed in mid-posterior to posterior portion of body. Birth pore inconspicuous, laterally posterior to pharynx. Cercariae variable in number, but present in all specimens examined, many at various stages of maturation.

\section{Remarks}

The redia of $C$. album examined in this study was morphologically consistent with descriptions of the redia of C. marginatum studied by Krull (1934) from Planorbella anceps Menke in Maryland, USA. The morphometric data presented by Krull (1934) were from the largest redia observed but fit the description of the redia of $C$. album, including the transverse rows of spines at the anterior portion of the body. Other
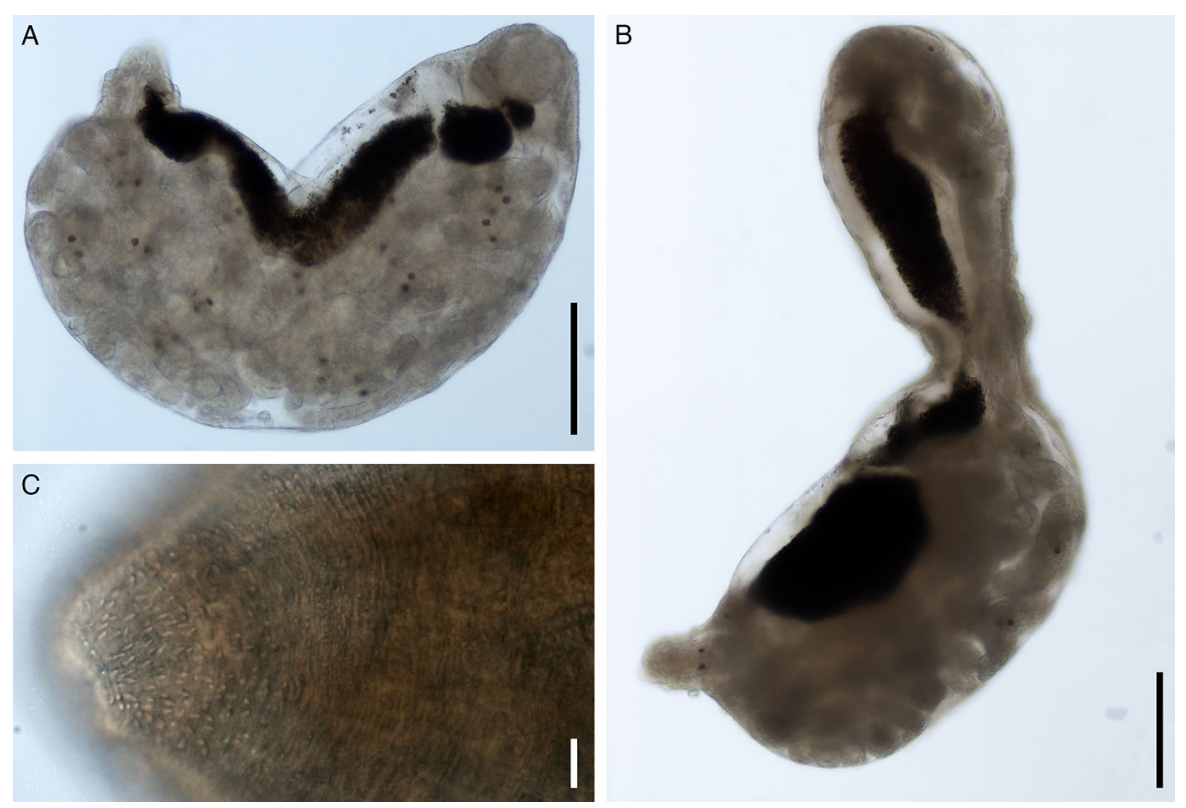

Fig. 3 Photomicrographs of unstained Clinostomum album rediae from Planorbella trivolvis collected from a catfish pond in Leflore County, Mississippi, USA. A-B, Whole rediae with numerous cercariae within; C, Anterior region showing transverse rows of spines. Scale-bars: A-B, $100 \mu \mathrm{m} ; \mathrm{C}, 10 \mu \mathrm{m}$ 


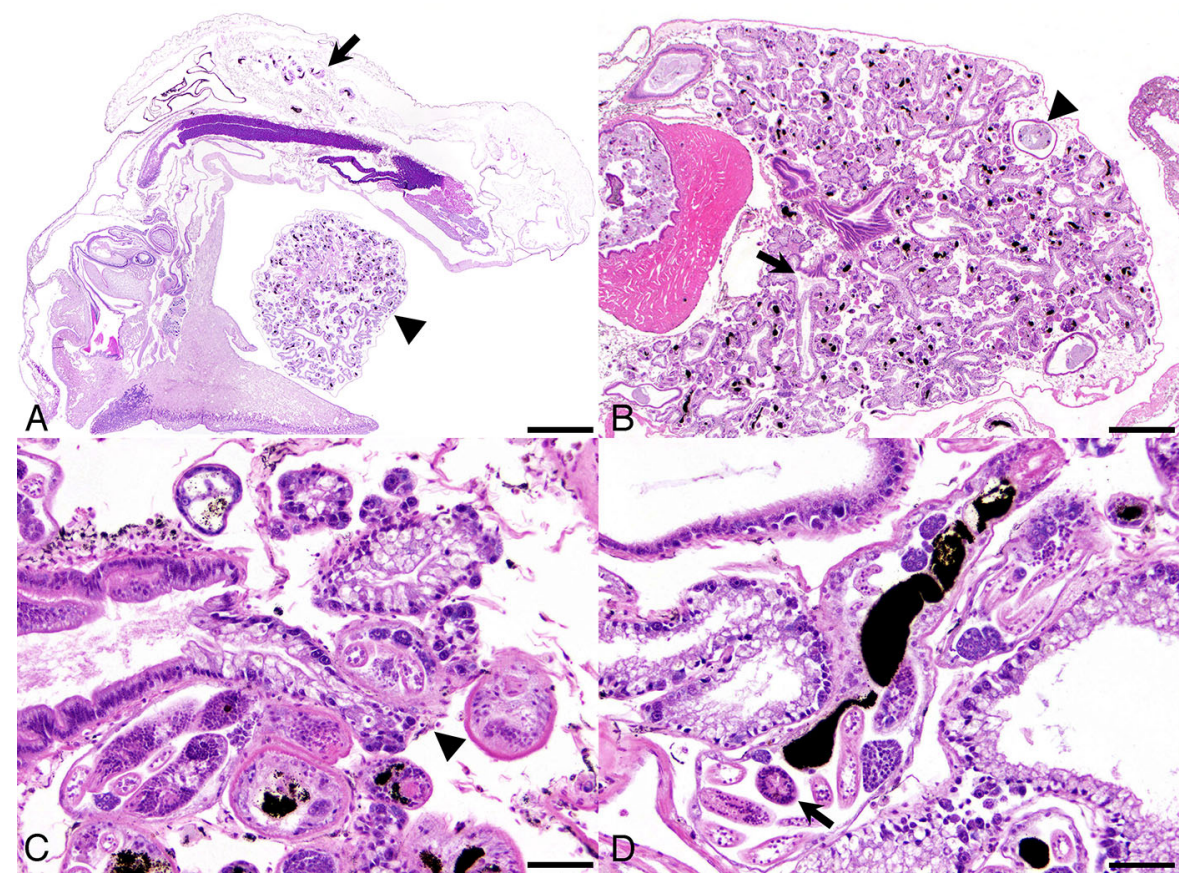

Fig. 4 Photomicrographs of Planorbella trivolvis infected with Clinostomum album collected from a catfish pond in Leflore County, Mississippi, USA. A, Subgross parasagittal view (PAS stain). Arrowhead denotes the atrophied digestive gland filled with rediae, arrow denotes rediae within the connective tissues of the lung; B, Digestive gland atrophy and heavy infection with rediae (black spots are pigment granules in rediae intestines) (HE stain). Arrow denotes digest gland tubule, arrowhead denotes intestine; C, Digestive gland tubule atrophy and compression by rediae, loss of interlobular connective tissue and fibrosis (HE stain). Arrowhead denotes a redia surrounded by fibrous tissue that blends into the basal aspect of the digestive gland tubule; D, A longitudinal profile of a redia in the interstitium of the digestive gland. Black granular pigment fills the intestine (HE stain). Arrow denotes a developing cercaria, admixed with clusters of germinal cells. Scale-bars: A, $1 \mathrm{~mm}$; B, $500 \mu \mathrm{m}$; C-D, $50 \mu \mathrm{m}$

descriptions of the redia of Clinostomum spp. (Nassi \& Bayssade-Dufour, 1980; Pinto et al., 2015) indicate the latter is much larger in terms of body length compared with the descriptions of redia in this study and the material examined by Krull (1934). However, each redia examined in this study and noted by Krull (1934) contained developed cercariae.

Larval parasites (rediae containing developing cercariae) were predominantly present in the interstitium of the digestive gland (hepatopancreas), and within the blood sinuses/connective tissues of the lung (Fig. 4A). Rediae contained many clusters of germinal cells admixed with developing cercariae, producing mature rediae that contained many developmental stages. Abundant fine black granular pigment filled redial intestines. The digestive gland exhibited marked atrophy of the lobules and loss of connective tissue, with concomitant expansion of the blood spaces where the parasites resided; parasite profiles comprised $50 \%$ or more of the tissue sections. Parasites within the digestive gland stroma were surrounded by a delicate layer of fibrous tissue containing small numbers of amoebocytes. Rediae were often attached to digestive tubule walls, but they were not seen to disrupt tubular epithelium or infiltrate digestive gland lumina. In some areas, marked fibrosis of the ducts with complete loss of lobules was seen. Cercariae were commonly present in the lumen of the gizzard and intestine as well. Rediae also occurred in the reproductive tissues and ovotestes were atrophied.

\section{Cercaria}

[Based on saline wet-mounts of 30 heat-killed cercariae from 3 separate snail hosts. Flame cells studied in live specimens stained with vital stains; see Table 2.] Cercaria lophocercous, brevifurcous, pharyngeate, typical of the genus Clinostomum. Body elongate, ovoid, shorter than tail stem region, 106-127 $(118 \pm 6) \times 28-38(33 \pm 2)($ Fig. 5). Eye-spots 2, present in the middle of cercarial body, 5-6 (6 \pm 0.6$)$ 
Table 2 Morphological data of Clinostomum spp. and brevifurcous cercariae from snails in the Americas

\begin{tabular}{|c|c|c|c|c|c|}
\hline \multirow{4}{*}{$\begin{array}{l}\text { Species } \\
\text { Host } \\
\text { Locality } \\
\text { Reference }\end{array}$} & \multirow{4}{*}{$\begin{array}{l}\text { Clinostomum album } \\
\text { Planorbella trivolvis } \\
\text { Mississippi, USA } \\
\text { This study }\end{array}$} & \multirow{4}{*}{$\begin{array}{l}\text { Clinostomum marginatum } \\
\text { Planorbella anceps } \\
\text { Maryland, USA } \\
\text { Krull (1934) }\end{array}$} & \multicolumn{2}{|c|}{ Cercaria ocellifera } & \multirow{4}{*}{$\begin{array}{l}\text { Clinostomum sp. } \\
\text { Biomphalaria glabrata, } \\
\text { B. straminea, B. tenagophild } \\
\text { Brazil } \\
\text { Pinto et al. (2015) }\end{array}$} \\
\hline & & & \multicolumn{2}{|c|}{ Biomphalaria tenagophila } & \\
\hline & & & \multicolumn{2}{|l|}{ Brazil } & \\
\hline & & & Ruiz (1953) & Moraes et al. (2009) & \\
\hline \multirow[t]{2}{*}{$\mathrm{BL}$} & $106-127$ & $120-138$ & $172-185$ & $126-132$ & $98-128$ \\
\hline & $(118)$ & $(130)$ & & & $(110)$ \\
\hline \multirow[t]{2}{*}{ BW } & $28-38$ & $30-32$ & - & $32-42$ & $32-42$ \\
\hline & (33) & $(31)$ & & & $(35)$ \\
\hline \multirow[t]{2}{*}{ TSL } & $198-239$ & $250-285$ & $339-390$ & $255-315$ & $273-307$ \\
\hline & $(223)$ & $(268)$ & & & $(288)$ \\
\hline \multirow[t]{2}{*}{ TSW } & $19-27$ & - & $30-37$ & - & $22-34$ \\
\hline & (23) & & & & $(27)$ \\
\hline \multirow[t]{2}{*}{ FL } & $85-108$ & $75-98$ & $123-195$ & $70-120$ & $86-106$ \\
\hline & $(95)$ & $(88)$ & & & $(95)$ \\
\hline \multirow[t]{2}{*}{ FW } & $11-17$ & - & - & - & $7-17$ \\
\hline & (14) & & & & (12) \\
\hline \multirow[t]{2}{*}{ AOL } & $36-53$ & $37-40$ & 53 & $0-32$ & $33-47$ \\
\hline & (43) & (39) & & & $(38)$ \\
\hline \multirow[t]{2}{*}{ AOW } & $18-25$ & - & 27 & - & $20-27$ \\
\hline & $(21)$ & & & & (24) \\
\hline
\end{tabular}

Abbreviations: BL, body length; BW, body width; TSL, tail stem length; TSW, tail stem width; FL, furcae length; FW, furcae width; AOL, anterior organ length; AOW, anterior organ width

$\times 5-6(6 \pm 0.4)$. Anterior organ elongate, ovoid, in anterior third of cercarial body, 36-53 $(43 \pm 4) \times$ $18-25(21 \pm 2)$. Ventral sucker not observed. Dorsal fin-fold not observed. Tail stem long, slender, 198-239 $(223 \pm 10) \times 19-27(23 \pm 2)$. Tail stem bifurcates into 2 short, tapering furcae with fin-folds, 85-108 $(95 \pm 6) \times 11-17(14 \pm 1)$. Flame-cell formula $2[(1+1)+(1+1)+[1])=10$.

Body armature: Approximately $4-5$ rows of minute pre-oral spines encircling the anterior region of cercarial body at level of anterior organ.

\section{Remarks}

The cercaria of C. album shares overlapping morphometric data with other clinostomid and brevifurcous cercariae described from freshwater snails in the Americas (Table 2). As with the redia, the cercaria of $C$. album closely resembles the cercaria of $C$. marginatum as described by Krull (1934) from $P$. anceps. Additionally, these also are consistent with the cercaria of a Clinostomum sp. described from three Biomphalaria spp. in Brazil, although the rediae were not morphologically consistent with $C$. album and molecular data support these as distinct species (Pinto et al., 2015).

\section{Metacercaria}

[Based on two Mayer's carmalum stained and mounted metacercaria, one designated as a hologenophore; see Table 3.] Body slender, linguiform, 4,081-4,938 (4509) × 737-874 (805), with slight constriction at level of ventral sucker (Fig. 6). Oral collar present. Oral sucker small, ovoid, 227-267 $(247) \times 268-297$ (283). Ventral sucker large, 593-666 $(629) \times 548-673(610)$, located in lower anterior third of body. Pharynx indistinct; prominent oesophageal bulb present just posterior to oral sucker. Intestinal caeca prominent, bifurcating just posterior to oral sucker, extending to posterior extremity of body, diverticulate broadly in regions posterior to ventral sucker. 


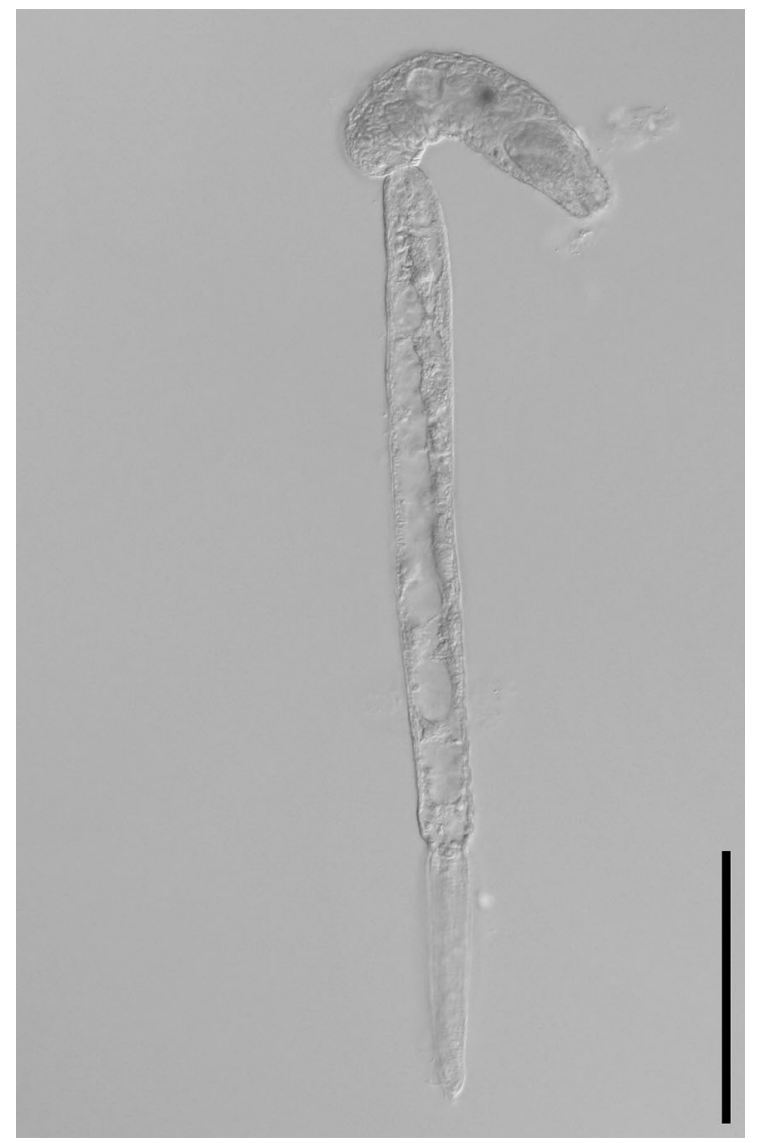

Fig. 5 Photomicrograph of a Clinostomum album cercaria shed from Planorbella trivolvis collected from a catfish pond in Leflore County, Mississippi, USA. Scale-bar: $100 \mu \mathrm{m}$

Gonads located in anterior portion of posterior third of body. Testes 2, located in body midline. Anterior testis lobed, 270-294 (282) × 333-334 (333). Posterior testis lobed, 273-364 (318) × 287-301 (294). Cirrus-sac located at level of anterior testis, overlapping its right anterior lobe, extends from right margin of body toward midline.

Ovary ovoid, intertesticular, 144-148 (146) $\times$ 125-132 (128). Genital pore visible, opening at body midline just anterior to anterior testis.

\section{Remarks}

Metacercariae of C. album are morphologically ambiguous and ranges for most morphological characters used to describe metacercaria overlap with $C$. marginatum, which is known to occur in cultured channel catfish (Lorio, 1989) and other forage fish in catfish production systems in Mississippi (Rosser et al., 2016b). Catfish experimentally challenged with C. album cercariae and controls contained no developing metacercariae suggesting that catfish are not a host for C. album.

\section{Molecular data of Clinostomum poteae n. sp. and larval stages of Clinostomum album}

Ribosomal regions (ITS1, 5.8S rRNA, and ITS2 region) for all four $C$. poteae specimens were identical. The top results of a Blastn search for the entire ribosomal region (partial 18S rRNA-ITS1-5.8S rRNA-ITS2-partial 28S rRNA) sequenced from a single specimen, were Clinostomum marginatum (99.5\% sequence similarity; $100 \%$ query coverage; KU708007; Rosser et al., 2017) and Clinostomum album (99.3\% sequence similarity; $100 \%$ query coverage; KU708008; Rosser et al., 2017) from a great egret in Mississippi, USA; Clinostomum cutaneum Paperna, 1964 (97.6\% sequence similarity; 95-96\% query coverage; GQ339114 and FJ609421; Gustinelli et al., 2010); and Clinostomum phalacrocoracis Dubois, 1931 (97.6\% sequence similarity; 96\% query coverage; FJ609422-FJ609423; Gustinelli et al., 2010) from the grey heron Ardea cinerea L. and Nile tilapia Oreochromis niloticus L. in Kenya. Additionally, $C$. poteae n. sp. shared $99.6 \%$ (38\% query coverage; AY222095; Olson et al., 2003) sequence similarity at the 28S rRNA gene with an unresolved Clinostomum sp. metacercaria from the North American bullfrog Lithobates catesbeiana Shaw in Tennessee, USA.

The partial c.550 bp cox 1 sequences of the four specimens were identical and no sequences in the NCBI database shared significant similarity sufficient to suggest conspecificity. The top hits of the BLASTn search were cox 1 sequences of $C$. attenuatum metacercariae from Lithobates clamitans Latreille and Lithobates pipiens Schreber in the USA and Quebec, Canada (88.2-88.5\% sequence similarity; 94-98\% query coverage; KP150305-KP1150306 and JF718585 and JF718587; Caffara et al., 2011; Locke et al., 2015).

For the ITS regions, interspecific variability was low between the Clinostomum spp. described from the Americas the application of ITS sequence data in species delineation is limited (Table 4). However, pairwise distances calculated from $\operatorname{cox} 1$ sequence data 
Table 3 Morphological data of Clinostomum spp. metacercariae from intermediate hosts in North America

\begin{tabular}{|c|c|c|c|c|c|c|c|}
\hline \multirow{2}{*}{$\begin{array}{l}\text { Species } \\
\text { Host }\end{array}$} & \multirow{2}{*}{$\begin{array}{l}\begin{array}{l}\text { Clinostomum } \\
\text { album }\end{array} \\
\begin{array}{l}\text { Pimephales } \\
\text { promelas }\end{array}\end{array}$} & \multirow{2}{*}{$\begin{array}{l}\begin{array}{l}\text { Clinostomum } \\
\text { sp. }\end{array} \\
\begin{array}{l}\text { Poecilia } \\
\text { reticulata }\end{array}\end{array}$} & \multirow{3}{*}{$\begin{array}{l}\begin{array}{l}\text { Clinostomum } \\
\text { heluans }\end{array} \\
\text { Cichla } \\
\text { temensis } \\
\text { Brazil }\end{array}$} & \multicolumn{3}{|c|}{ Clinostomum marginatum } & \multirow{3}{*}{$\begin{array}{l}\text { Clinostomит } \\
\text { tatxитиi } \\
\text { Dormitator } \\
\text { maculatus } \\
\text { Mexico }\end{array}$} \\
\hline & & & & Perciformes & $\begin{array}{l}\text { Dormitator } \\
\text { maculatus }\end{array}$ & $\begin{array}{l}\text { Menidia } \\
\text { beryllina }\end{array}$ & \\
\hline Locality & $\begin{array}{l}\text { Mississippi, } \\
\text { USA }\end{array}$ & Brazil & & Canada & Mexico & $\begin{array}{l}\text { Mississippi, } \\
\text { USA }\end{array}$ & \\
\hline Reference & This study & $\begin{array}{l}\text { Pinto et al. } \\
(2015)\end{array}$ & $\begin{array}{l}\text { Vicente et al. } \\
(1978)\end{array}$ & $\begin{array}{l}\text { Caffara et al. } \\
\text { (2011) }\end{array}$ & $\begin{array}{l}\text { Sereno-Uribe } \\
\text { et al. (2013) }\end{array}$ & $\begin{array}{l}\text { Rosser et al. } \\
(2016)\end{array}$ & $\begin{array}{l}\text { Sereno-Uribe } \\
\text { et al. (2013) }\end{array}$ \\
\hline $\mathrm{BL}$ & $\begin{array}{l}4,081-4,938 \\
(4,509)\end{array}$ & $\begin{array}{l}3,610-5,553 \\
(4,224)\end{array}$ & $2,000-2,200$ & $\begin{array}{l}4,215-6,346 \\
(5,402)\end{array}$ & $\begin{array}{l}2,770-4,100 \\
(3,300)\end{array}$ & $\begin{array}{l}3,128-5,407 \\
(3,968)\end{array}$ & $\begin{array}{l}2,390-3,950 \\
(2,940)\end{array}$ \\
\hline BW & $\begin{array}{l}737-874 \\
(805)\end{array}$ & $\begin{array}{l}1,031-1,616 \\
(1,215)\end{array}$ & $640-740$ & $\begin{array}{l}979-1,532 \\
(1,329)\end{array}$ & $\begin{array}{l}600-850 \\
(730)\end{array}$ & $\begin{array}{l}904-1,303 \\
(1,068)\end{array}$ & $\begin{array}{l}340-840 \\
(593)\end{array}$ \\
\hline OsL & $\begin{array}{l}227-267 \\
(247)\end{array}$ & $\begin{array}{l}170-239 \\
(213)\end{array}$ & $120-150$ & $\begin{array}{l}238-599 \\
(312)\end{array}$ & $\begin{array}{l}160-220 \\
(183)\end{array}$ & $\begin{array}{l}192-281 \\
(222)\end{array}$ & $\begin{array}{l}140-210 \\
(160)\end{array}$ \\
\hline OsW & $\begin{array}{l}268-297 \\
(283)\end{array}$ & $\begin{array}{l}232-273 \\
(251)\end{array}$ & $120-140$ & $\begin{array}{l}194-586 \\
(290)\end{array}$ & $\begin{array}{l}170-220 \\
(196)\end{array}$ & $\begin{array}{l}191-241 \\
(215)\end{array}$ & $\begin{array}{l}150-210 \\
(174)\end{array}$ \\
\hline VsL & $\begin{array}{l}593-666 \\
(629)\end{array}$ & $\begin{array}{l}602-746 \\
(685)\end{array}$ & $200-420$ & $\begin{array}{l}510-757 \\
(669)\end{array}$ & $\begin{array}{l}430-620 \\
(496)\end{array}$ & $\begin{array}{l}468-666 \\
(560)\end{array}$ & $\begin{array}{l}350-560 \\
(420)\end{array}$ \\
\hline VsW & $\begin{array}{l}548-673 \\
(610)\end{array}$ & $\begin{array}{l}602-756 \\
(684)\end{array}$ & $230-290$ & $\begin{array}{l}571-804 \\
(708)\end{array}$ & $\begin{array}{l}450-620 \\
(530)\end{array}$ & $\begin{array}{l}485-606 \\
(542)\end{array}$ & $\begin{array}{l}320-570 \\
(431)\end{array}$ \\
\hline DS & - & $\begin{array}{l}515-860 \\
(659)\end{array}$ & - & $\begin{array}{l}959-1,491 \\
(1,243)\end{array}$ & $\begin{array}{l}380-700 \\
(539)\end{array}$ & - & $\begin{array}{l}350-610 \\
(468)\end{array}$ \\
\hline ATL & $\begin{array}{l}270-294 \\
(282)\end{array}$ & $\begin{array}{l}137-206 \\
(159)\end{array}$ & 56 & $\begin{array}{l}231-413 \\
(307)\end{array}$ & $\begin{array}{l}180-370 \\
(224)\end{array}$ & $\begin{array}{l}130-242 \\
(190)\end{array}$ & $\begin{array}{l}120-250 \\
(171)\end{array}$ \\
\hline ATW & $\begin{array}{l}333-334 \\
(333)\end{array}$ & $\begin{array}{l}137-226 \\
(142)\end{array}$ & $84-120$ & $\begin{array}{l}264-498 \\
(389)\end{array}$ & $\begin{array}{l}200-350 \\
(247)\end{array}$ & $\begin{array}{l}213-361 \\
(278)\end{array}$ & $\begin{array}{l}140-275 \\
(200)\end{array}$ \\
\hline PTL & $\begin{array}{l}273-364 \\
(318)\end{array}$ & $\begin{array}{l}178-259 \\
(217)\end{array}$ & 56 & $\begin{array}{l}233-457 \\
(327)\end{array}$ & $\begin{array}{l}170-270 \\
(214)\end{array}$ & $\begin{array}{l}153-230 \\
(189)\end{array}$ & $\begin{array}{l}115-230 \\
(172)\end{array}$ \\
\hline PTW & $\begin{array}{l}287-301 \\
(294)\end{array}$ & $\begin{array}{l}116-311 \\
(172)\end{array}$ & $84-120$ & $\begin{array}{l}295-492 \\
(405)\end{array}$ & $\begin{array}{l}250-400 \\
(280)\end{array}$ & $\begin{array}{l}159-306 \\
(239)\end{array}$ & $\begin{array}{l}180-320 \\
(230)\end{array}$ \\
\hline OvL & $\begin{array}{l}144-148 \\
(146)\end{array}$ & $\begin{array}{l}89-147 \\
(110)\end{array}$ & $50-110$ & $\begin{array}{l}85-142 \\
(115)\end{array}$ & $\begin{array}{l}80-120 \\
(98)\end{array}$ & $\begin{array}{l}121-171 \\
(144)\end{array}$ & $\begin{array}{l}72-130 \\
(96)\end{array}$ \\
\hline $\mathrm{OvW}$ & $\begin{array}{l}125-132 \\
(128)\end{array}$ & $\begin{array}{l}68-120 \\
(85)\end{array}$ & $90-150$ & $\begin{array}{l}62-97 \\
(80)\end{array}$ & $\begin{array}{l}60-90 \\
(73)\end{array}$ & $\begin{array}{l}169-275 \\
(233)\end{array}$ & $\begin{array}{l}42-111 \\
(70)\end{array}$ \\
\hline CSL & - & $\begin{array}{l}150-205 \\
(183)\end{array}$ & - & $\begin{array}{l}172-343 \\
(256)\end{array}$ & $\begin{array}{l}180-220 \\
(200)\end{array}$ & - & $\begin{array}{l}137-225 \\
(179)\end{array}$ \\
\hline CSW & - & $\begin{array}{l}89-164 \\
(121)\end{array}$ & - & $\begin{array}{l}119-153 \\
(137)\end{array}$ & $\begin{array}{l}90-120 \\
(106)\end{array}$ & - & $\begin{array}{l}65-125 \\
(91)\end{array}$ \\
\hline
\end{tabular}

Abbreviations: BL, body length; BW, body width; OsL, oral sucker length; OsW, oral sucker width; VsL, ventral sucker length; VsW, ventral sucker width; DS, distance between oral and ventral sucker; ATL, anterior testis length; ATW, anterior testis width; PTL, posterior testis length; PTW, posterior testis width; OvL, ovary length; OvW, ovary width; CSL, cirrus-sac length; CSW; cirrus-sac width

for C. album cercaria and metacercaria reported here, and an adult $C$. album from previous work (Rosser et al., 2017) had high (>10\%) interspecific diversity and low $(<1 \%)$ intraspecific variability compared to the other Clinostomum spp. (Table 5). The values reported here are consistent with previous studies 


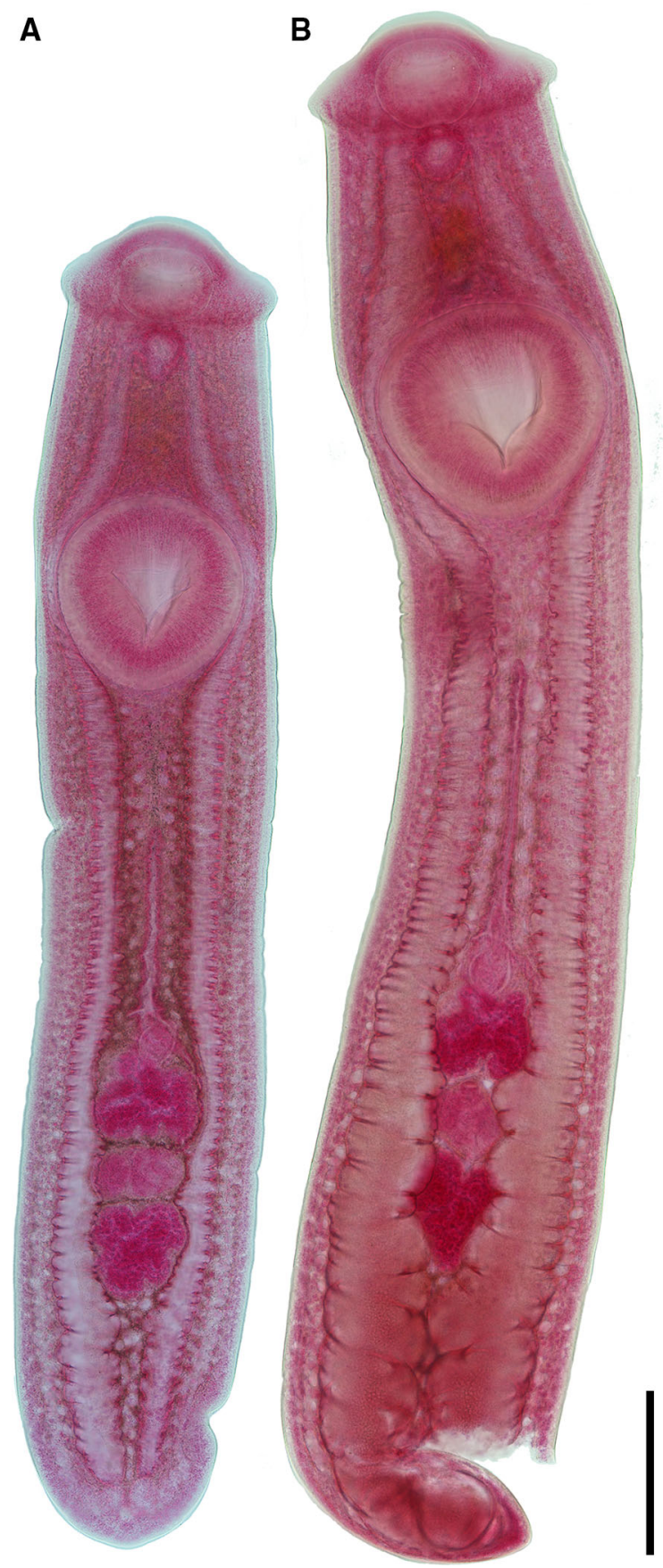

Fig. 6 Photomicrographs of Mayer's carmalum-stained Clinostomum album metacercariae from Pimephales promelas collected in Lowndes County, Mississippi, USA. A, Voucher; B, Hologenophore. Scale-bar: $500 \mu \mathrm{m}$

involving representatives of the Clinostomoidea suggesting the cercariae and metacercaria from this study and adult stages of C. album are conspecific (Sereno-
Uribe et al., 2013; Senapin et al., 2014; Locke et al., 2015; Caffara et al., 2017; Woodyard et al., 2017). Likewise, pairwise distances for the nad 1 between the Clinostomum spp. in this study had low intraspecific variability and a greater interspecific variability compared to $\operatorname{cox} 1$, consistent with previous studies investigating genetic diversity of the mitochondrial genes of the Echinostomatidae Looss, 1899 (Morgan \& Blair, 1998; Detwiler et al., 2010) (Table 6). The molecular data presented here evince the cercaria and metacercaria in this study represent previously unidentified stages in the life-cycle of C. album in Mississippi, USA.

Bayesian inference and maximum likelihood analyses of the concatenated cox 1, ITS1, 5.8S rRNA gene, and ITS2 DNA sequences were consistent with previous phylogenies of the Clinostomidae (Figure 7). Clinostomum poteae $\mathrm{n}$. sp. forms a clade within the larger grouping of American clinostomids, Clinostomum marginatum, $C$. attenuatum and $C$. album, but was basal to $C$. marginatum and $C$. attenuatum. Branches were strongly supported by high posterior probability and bootstrap values.

\section{Discussion}

For almost 200 years researchers have debated the systematics of clinostomids. The advent of molecular techniques and the ability to supplement morphological data with nucleotide sequence data has identified the clinostomids as a truly diverse group of trematodes, with new species described regularly (Caffara et al., 2011; Sereno-Uribe et al., 2013; Locke et al., 2015; Pérez-Ponce de León et al., 2016; Rosser et al., 2017). Currently, six Clinostomum spp. are recognised in North America based on detailed morphological descriptions of stained and mounted adults recovered from avian hosts (Bravo-Hollis, 1947; Hutton \& Sogandares-Bernal, 1960; Caffara et al., 2011; Pérez-Ponce de León et al., 2016; Rosser et al., 2017). Of these, few Clinostomum spp. are described or observed in American cormorants and even fewer are documented from the trachea. Herein C. poteae n. sp. from the trachea of a double-crested cormorant in Mississippi, USA, is described and the larval stages of the life-cycle of $C$. album are identified.

Clinostomum poteae n. sp. differs from many of the Clinostomum spp. in the Americas by location within the host (trachea vs oesophagus and oral cavity), but 
Table 4 Pairwise distances calculated from ITS region sequences of Clinostomum poteae n. sp. and Clinostomum album from the alignment in this study. Values are presented as average number of base differences per site followed by the range in parentheses

\begin{tabular}{llr}
\hline & Clinostomum poteae $\mathrm{n} . \mathrm{sp}$. & Clinostomum album \\
\hline Clinostomum poteae $\mathrm{n} . \mathrm{sp}$. & $0.000(0.000-0.000)$ & $0.007(0.007-0.007)$ \\
Clinostomum album & $0.007(0.007-0.007)$ & $0.000(0.000-0.000)$ \\
Clinostomum attenuatum & $0.002(0.002-0.002)$ & $0.005(0.005-0.005)$ \\
Clinostomum complanatum & $0.042(0.042-0.042)$ & $0.049(0.049-0.049)$ \\
Clinostomum cutaneum & $0.034(0.034-0.034)$ & $0.041(0.041-0.041)$ \\
Clinostomum detruncatum & $0.029(0.029-0.029)$ & $0.029(0.029-0.029)$ \\
Clinostomum heluans & $0.024(0.024-0.024)$ & $0.022(0.022-0.022)$ \\
Clinostomum marginatum & $0.002(0.002-0.002)$ & $0.005(0.005-0.005)$ \\
Clinostomum phalacrocoracis & $0.036(0.036-0.036)$ & $0.042(0.042-0.042)$ \\
Clinostomum philippinense & $0.037(0.037-0.037)$ & $0.044(0.044-0.044)$ \\
Clinostomum tataxumui & $0.022(0.022-0.022)$ & $0.025(0.025-0.025)$ \\
Clinostomum tilapiae & $0.032(0.032-0.032)$ & $0.039(0.039-0.039)$ \\
Clinostomum sp. 1 & $0.019(0.019-0.019)$ & $0.022(0.022-0.022)$ \\
Clinostomum sp. 3 & $0.019(0.019-0.019)$ & $0.022(0.022-0.022)$ \\
Clinostomum sp. 4 & $0.017(0.017-0.017)$ & $0.020(0.020-0.020)$ \\
Clinostomum sp. 5 & $0.022(0.022-0.022)$ & $0.025(0.025-0.025)$ \\
Clinostomum sp. 7 & $0.034(0.034-0.034)$ & $0.037(0.037-0.037)$ \\
Clinostomum sp. 8 & $0.044(0.044-0.044)$ & $0.051(0.051-0.051)$ \\
\hline & &
\end{tabular}

Table 5 Pairwise distances calculated from $\operatorname{cox} 1$ sequences of Clinostomum poteae n. sp. and Clinostomum album from the alignment in this study. Values are presented as average number of base differences per site followed by the range in parentheses

\begin{tabular}{llr}
\hline & Clinostomum poteae $\mathrm{n} . \mathrm{sp}$. & Clinostomum album \\
\hline Clinostomum poteae $\mathrm{n} . \mathrm{sp}$. & $0.000(0.000-0.000)$ & $0.174(0.172-0.179)$ \\
Clinostomum album & $0.174(0.172-0.179)$ & $0.004(0.000-0.008)$ \\
Clinostomum attenuatum & $0.121(0.121-0.211)$ & $0.149(0.148-0.152)$ \\
Clinostomum complanatum & $0.171(0.170-0.172)$ & $0.203(0.201-0.209)$ \\
Clinostomum cutaneum & $0.176(0.175-0.177)$ & $0.180(0.150-0.187)$ \\
Clinostomum detruncatum & $0.149(0.149-0.149)$ & $0.155(0.150-0.158)$ \\
Clinostomum heluans & $0.181(0.181-0.181)$ & $0.196(0.195-0.199)$ \\
Clinostomum marginatum & $0.138(0.136-0.136)$ & $0.156(0.150-0.164)$ \\
Clinostomum phalacrocoracis & $0.174(0.172-0.175)$ & $0.190(0.183-0.193)$ \\
Clinostomum philippinense & $0.201(0.201-0.201)$ & $0.204(0.201-0.207)$ \\
Clinostomum tataxumui & $0.151(0.150-0.152)$ & $0.180(0.175-0.185)$ \\
Clinostomum tilapiae & $0.177(0.177-0.177)$ & $0.192(0.187-0.197)$ \\
Clinostomum sp. 1 & $0.142(0.142-0.142)$ & $0.146(0.144-0.150)$ \\
Clinostomum sp. 3 & $0.148(0.148-0.148)$ & $0.159(0.158-0.162)$ \\
Clinostomum sp. 4 & $0.138(0.138-0.138)$ & $0.143(0.140-0.148)$ \\
Clinostomum sp. 5 & $0.156(0.156-0.156)$ & $0.162(0.160-0.166)$ \\
Clinostomum sp. 7 & $0.179(0.179-0.179)$ & $0.211(0.207-0.216)$ \\
Clinostomum sp. 8 & $0.172(0.170-0.172)$ & $0.196(0.191-0.201)$ \\
\hline
\end{tabular}


Table 6 Pairwise distances calculated from nad1 sequences of Clinostomum poteae n. sp. and Clinostomum album from the alignment in this study. Values are presented as average number of base differences per site followed by the range in parentheses

\begin{tabular}{lll}
\hline & Clinostomum poteae $\mathrm{n} . \mathrm{sp}$. & Clinostomum album \\
\hline Clinostomum poteae $\mathrm{n} . \mathrm{sp}$. & $0.000(0.000-0.000)$ & - \\
Clinostomum album & $0.196(0.195-0.198)$ & $0.0005(0.000-0.0028)$ \\
Clinostomum marginatum & $0.180(0.178-0.181)$ & $0.175(0.173-0.176)$ \\
\hline
\end{tabular}

also based on morphometric and molecular data. Clinostomum intermedialis was described by Lamont (1920) from the oesophagus of a single Neotropic cormorant from Lake Valencia, Venezuela. In Lamont's description, few morphological characters were measured although the description is detailed and informative when considering the placement of the organs. Clinostomum intermedialis differs considerably from other Clinostomum spp. in having an ovoid anterior testis located in the left margin of the body compared to C. poteae n. sp. in which the anterior testis is distinctly lobed and situated near the body midline, similar to other Clinostomum congeners (Caffara et al., 2011; Sereno-Uribe et al., 2013; Rosser et al., 2017). Although similar in size, we believe these to be distinctly different from $C$. intermedialis, as all mounted C. poteae n. sp. specimens were consistent in the placement and size of the reproductive organs. Later, Bravo-Hollis (1947) supplemented the descriptions of $C$. intermedialis and $C$. heluans with new specimens collected from the pharynx of Brandt's cormorant from Nuevo León, Mexico. Molecular data have yet to be provided for $C$. intermedialis to support these morphological differences, although now $C$. intermedialis is considered a species of Clinostomatopsis (Lunaschi \& Drago, 2009).

Clinostomum attenuatum has been reported in Florida cormorants from Florida, USA (Hutton \& Sogandares-Bernal, 1960; Hutton, 1964). In Mexico, Clinostomum tataxumui was recently recognised as a novel species in the buccal cavity of great egrets, great-blue herons Ardea herodias L. and the barethroated tiger heron Tigrisoma mexicanum Swainson (see Sereno-Uribe et al., 2013). Clinostomum marginatum has also been reported from the trachea and lungs of double-crested cormorants in Florida, although no morphological data were reported to justify this species level designation and no molecular data exist from these specimens (Threlfall, 1982). Additionally, C. marginatum has been reported in the oral cavity of the Neotropic cormorant in Brazil (Travassos et al., 1969). When compared to specimens of $C$. marginatum and $C$. album collected from great egrets in Mississippi, C. poteae n. sp. is noticeably larger across many morphological characters and is found within the trachea. Meanwhile both C. marginatum and C. album were recovered from the oral cavity and oesophagus (Rosser et al., 2017). In light of the often morphologically ambiguous nature of Clinostomum spp. (and other trematode genera) adults and larval forms, the examination of multiple specimens and the inclusion of a hologenophore creates a more compelling case for species identification. Although morphological analysis should be the basis of identification of these organisms at first glance, supporting molecular data offers a more robust identification and hologenophores are recommended in novel species descriptions moving forward.

In addition to morphological differences, the specimens of $C$. poteae n. sp. were molecularly distinct from other Clinostomum spp. for which cox 1 sequencing data exists. The interspecific variability at the cox 1 gene was consistent with that previously described for the genus (Locke et al., 2015; Caffara et al., 2017) and phylogenetic analyses demonstrated $C$. poteae n. sp. formed a distinct clade, sister to other Clinostomum spp. collected from the Americas (Caffara et al., 2011; Locke et al., 2015; Rosser et al., 2017).

Remarkably, given the number of described species and their importance as parasites of fish and amphibians, few Clinostomum spp. life-cycles are known. In Brazil, the life-cycle of a Clinostomum sp. was described from naturally infected avian, molluscan and fish hosts (Dias et al., 2003). Adult specimens designated as $C$. complanatum were collected from Ardea cocoi L., A. alba, Egretta thula Molina, and P. 


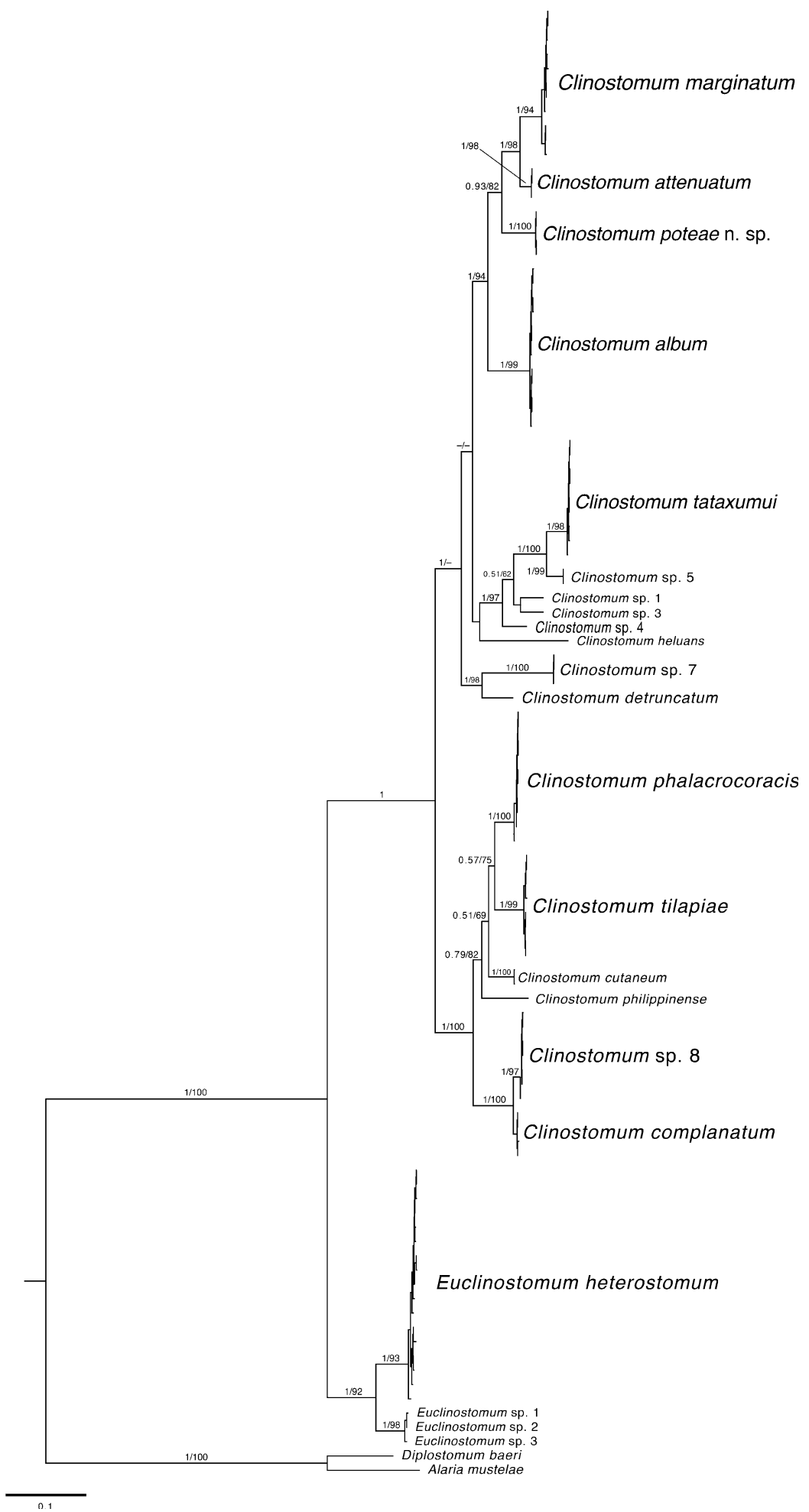

Fig. 7 Phylogenetic tree constructed from concatenated cox 1 gene and ITS regions alignment. Numbers above the branches represent Bayesian posterior probabilities and maximum likelihood bootstrap values based on 1,000 pseudoreplicates $(<0.5$ are not shown). Clinostomum species obtained in this study are in bold. Scale-bar: average number of nucleotide substitutions per site 
brasilianus in the Americas, but the identity of these isolates is debated. A malacological survey performed in this study identified the planorbid snail Biomphalaria peregrina as the only snail species releasing clinostomid cercariae $(0.75 \%$ prevalence $)$. When laboratory raised banded knife fish Gymnotus carapo L. were exposed to these cercariae, a metacercaria consistent with $C$. complanatum was observed developing on an operculum 42 dpi (Dias et al., 2003). Metacercariae were also reported from several wild siluriform fish, including Loricariichthys platymetopon, Isbrücker \& Nijssen, Parauchenipterus galeatus L., Hoplosternum littorale Hancock and Loricaria sp. L. Metacercariae consistent with $C$. complanatum were also observed in a single characiform fish, Hoplias malabaracius Block (see Dias et al., 2003).

In the USA, significant research investment regarding the life-cycle of $C$. marginatum has been made over the past century. The planorbid snail $P$. trivolvis has been identified as the first intermediate host and development of larval stages within the snail have been extensively studied, both from wild, naturally infected populations, as well as under experimental conditions. Edney (1950) demonstrated that laboratory reared marsh rams-horn snails as young as one day to two months were susceptible to infection, but older cohorts (1-2 years) were not capable of being infected. Snails are possibly infected early in life and are capable of maintaining infections for several years, continually producing rediae and cercariae (Edney, 1950). Consistent with previous studies concerning the pathology of larval trematode infections in snails, the digestive gland and gonad were severely atrophied in C. album-infected Planorbella trivolvis. Little to no inflammation or necrosis was observed, suggesting that atrophy is associated with mechanical destruction attributed to direct ingestion of host tissues or the appropriation of nutrients from the host (Crews, 1987). Although rediae were not observed actively feeding on snail tissues, the presence of intestinal black pigment suggests these stages were feeding on host tissues. Parasites were present in the connective tissues and blood spaces of the snails, which is also typical of many snail-trematode parasitic relationships. The presence of cercariae in the gizzard and intestine is not usually noted, and this may be due to the snail feeding on cercariae shed into the environment. The metacercariae of $C$. marginatum are widely distributed throughout the Americas and have been reported from a myriad of fish and amphibian hosts (Hoffmann, 1999; McAllister, 1990; Miller et al., 2004), though many of these are not supported by molecular data and could represent currently unidentified species. The ability to distinguish Clinostomum spp. based on cercaria morphometric data alone is likely unreliable, especially when conducting experimental challenges or elucidating life-cycles with specimens collected from naturally infected hosts in areas where multiple species share a given geographical locality or population of hosts. The usefulness of molecular data obtained from larval stages is already known from previous studies of Clinostomum spp. (Gustinelli et al., 2010; Caffara et al., 2017).

Comparably, based on molecular data obtained here, the life-cycle of $C$. album includes the ramshorn snail as a first intermediate host, fathead minnows as a second intermediate host, and great egrets as a definitive host (Rosser et al., 2017). Given the diverse number of potential hosts for any given Clinostomum sp., it is likely that other hosts exist but have yet to be identified and the health impacts on baitfish species such as the fathead minnow remain unknown. Experimental infections in channel catfish were unsuccessful and did not result in detectable metacercariae up to 60 dpi. Comparably, similar studies in catfish have demonstrated development and persistence of $C$. marginatum metacercariae for periods $>100$ days post-exposure (Doffitt, 2011).

The larval stages of $C$. poteae n. sp. remain unknown, but molecular data generated in this study will aid in the elucidation of the life-cycle when cercaria and metacercaria stages are encountered in future studies of clinostomids in mollusc, fish, or amphibian hosts. The utility of molecular data in parasitological studies remains in its infancy but will likely continue to aid in the elucidation of life-cycles of various parasitic groups and should remain an integral component of novel species descriptions. Further work examining the diversity and effects on fish and amphibian health of clinostomids in their avian hosts in the southeastern United States is warranted.

Acknowledgements This study was supported in part by the Mississippi State University College of Veterinary Medicine, the Mississippi Agricultural and Forestry Experiment Station, and the USDA-ARS Catfish Health Initiative (CRIS 6402-31320-002-02). The authors would like to sincerely thank Allison Wise for assistance in collecting snails used in 
this study and recognise her participation in the 2017 International Science and Engineering Fair with her project "Survey and Shedding Characteristics of Trematodes in Catfish Ponds".

\section{Compliance with ethical standards}

Conflict of interest The authors declare that they have no conflict of interest.

Ethical approval All applicable institutional, national and international guidelines for the care and use of animals were followed (IACUC QA 2458).

\section{References}

Acosta, A. A., Caffara, M., Fioravanti, M. L., Utsunomia, R., Zago, A. C., Franceschini, L., et al. (2016). Morphological and molecular characterization of Clinostomum detruncatum (Trematoda: Clinostomidae) metacercariae infecting Synbranchus marmoratus. Journal of Parasitology, 102, 151-156.

Alberson, N. R., Rosser, T. G., Buddenborg, S. K., Khoo, L. H., Loker, E. S., Richardson, T. D., et al. (2017). North and South American haplotypes of Drepanocephalus auritus (Digenea: Echinostomatidae) are released from Biomphalaria havanensis (Mollusca: Planorbidae) inhabiting catfish aquaculture ponds in Mississippi, USA. Comparative Parasitology, 84, 87-101.

Altschul, S. F., Gish, W., Miller, W., Myers, E. W., \& Lipman, D. J. (1990). Basic local alignment search tool. Journal of Molecular Biology, 215, 403-410.

Bengtsson-Palme, J., Ryberg, M., Hartmann, M., Branco, S., Wang, Z., Godhe, A., et al. (2013). Improved software detection and extraction of ITS1 and ITS2 from ribosomal ITS sequences of fungi and other eukaryotes for analysis of environmental sequencing data. Methods in Ecology and Evolution, 4, 914-919.

Blasco-Costa, I., Cutmore, S. C., Miller, T. L., \& Nolan, M. J. (2016). Molecular approaches to trematode systematics: 'best practice' and implications for future study. Systematic Parasitology, 93, 295-306.

Bravo-Hollis, M. (1947). Dos especies de Clinostomum (Trematoda), de aves procedentes del estado de Nuevo León, México. Anales del Instituto de Biología, México, 18, 489-498.

Briosio-Anguilar, R., Pinto, H. A., Rodríguez-Santiago, M. A., López-García, K., Garcia-Varela, M., \& Perez-Ponce de Leon, G. (2018). Link between the adult and the metacercaria of Clinostomum heluans Braun, 1899 (Trematoda: Clinostomidae) through DNA sequence and its phylogenetic position within the genus Clinostomum Leidy, 1856. Journal of Parasitology. https://doi.org/10.1645/17-183.

Caffara, M., Locke, S. A., Echi, P. C., Halajian, A., Benini, D., Luus-Powell, W. J., et al. (2017). A morphological and molecular study of clinostomid metacercariae from
African fish with a redescription of Clinostomum tilapiae. Parasitology, 144, 1519-1529.

Caffara, M., Locke, S. A., Gustinelli, A., Marcogliese, D. J., \& Fioravanti, M. L. (2011). Morphological and molecular differentiation of Clinostomum complanatum and Clinostomum marginatum (Digenea: Clinostomidae) metacercariae and adults. Journal of Parasitology, 97, 884-891.

Crews, A., \& Esch, G. W. (1987). Histopathology of larval trematode infections in the freshwater pulmonate snail, Helisoma anceps. Journal of Invertebrate Pathology, 49, 76-82.

Criscione, C. D., Poulin, R., \& Blouin, M. S. (2005). Molecular ecology of parasites: Elucidating ecological and microevolutionary processes. Molecular Ecology, 14, 2247-2257.

Detwiler, J. T., Bos, D. H., \& Minchella, D. J. (2010). Revealing the secret lives of cryptic species: Examining the phylogenetic relationships of echinostome parasites in North America. Molecular Phylogenetics and Evolution, 55, 611-620.

Dias, M. L. G. G., Eiras, J. C., Machado, M. H., Souza, G. T. R., \& Pavanelli, G. C. (2003). The life cycle of Clinostomum complanatum Rudolphi, 1814 (Digenea, Clinostomidae) on the floodplain of the high Paraná river, Brazil. Parasitology Research, 89, 506-508.

Doffitt, C. M. (2011). Life history of two digenetic trematodes, Bolbophorus damnificus and an unknown clinostomid species, that infect channel catfish (Ictalurus punctatus). $\mathrm{PhD}$ thesis, Mississippi State University, Mississippi State.

Edney, J. M. (1950). Productivity in Clinostomum marginatum (Trematoda: Clinostomatidae). Transactions of the American Microscopical Society, 69, 186-188.

Glahn, J. F., Harrel, J. B., \& Vyles, C. (1998). The diet of wintering double-crested cormorants feeding at lakes in the southeastern United States. Colonial Waterbirds, 21, 431-437.

Glahn, J. F., \& King, D. T. (2004). Bird depredation. In: Tucker, C. S. \& Hargreaves J. A. (Eds.), Biology and Culture of Channel Catfish. Amsterdam: Elsevier, pp. 503-529.

Griffin, M. J., Khoo, L. H., Quiniou, S. M., O’Hear, M. M., Pote, L. M., Greenway, T. E., et al. (2012). Genetic sequence data identifies the cercaria of Drepanocephalus spathans (Digenea: Echinostomatidae), a parasite of the doublecrested cormorant (Phalacrocorax auritus), with notes on its pathology in juvenile channel catfish (Ictalurus punctatus). Journal of Parasitology, 98, 967-972.

Griffin, M. J., Khoo, L. H., Steadman, J. M., Ware, C., Quiniou, S. M., Mischke, C. C., et al. (2014). Chronic pathology and longevity of Drepanocephalus spathans infections in juvenile channel catfish. Journal of Aquatic Animal Health, 26, 210-218.

Gustinelli, A., Caffara, M., Florio, D., Otachi, E. O., Wathuta, E. M., \& Fiorvanti, M. L. (2010). First description of the adult stage of Clinostomum cutaneum Paperna, 1964 (Digenea: Clinostomidae) from grey herons Ardea cinerea L. and a redescription of the metacercaria from the Nile tilapia Oreochromis niloticus niloticus (L.) in Kenya. Systematic Parasitology, 76, 39-51.

Hawke, J. P., \& Khoo, L. H. (2004). Infectious diseases. In: Tucker, C. S. \& Hargreaves J. A. (Eds), Biology and 
Culture of Channel Catfish. Amsterdam: Elsevier, pp. 387-443.

Hoffman, G. L. (1999). Parasites of North American freshwater fishes. New York: Cornell University Press.

Hutton, R. F. (1964). A second list of parasites from marine and coastal animals of Florida. Transactions of the American Microscopical Society, 83, 439-447.

Hutton, R. F., \& Sogandares-Bernal, F. (1960). Studies on helminth parasites from the coast of Florida. II. Digenetic trematodes from shore birds of the west coast of Florida. 1. Bulletin of Marine Science of the Gulf and Caribbean, 10, 40-54.

ICZN (2012). International Commission on Zoological Nomenclature: Amendment of articles 8, 9, 10, 21 and 78 of the International Code of Zoological Nomenclature to expand and refine methods of publication. Bulletin of Zoological Nomenclature, 69, 161-169.

Katoh, K., Misawa, K., Kuma, K., \& Miyata, T. (2002). MAFFT: A novel method for rapid multiple sequence alignment based on fast Fourier transform. Nucleic Acids Research, 30, 3059-3066.

Katoh, K., \& Standley, D. M. (2013). MAFFT multiple sequence alignment software version 7: Improvements in performance and usability. Molecular Biology and Evolution, 30, 772-780.

Krull, W. H. (1934). Some observations on the cercaria and redia of a species of Clinostomum, apparently $C$. marginatum (Rudolphi, 1819) (Trematoda: Clinostomidae). Proceedings of the Helminthological Society of Washington, 1, 34-35.

Kumar, S., Stecher, G., \& Tamura, K. (2016). MEGA7: Molecular evolutionary genetics analysis version 7.0 for bigger datasets. Molecular Biology and Evolution, 33, 1870-1874.

Lamont, M. E. (1920). A new species of Clinostomum. Occasional Papers of the Museum of Zoology, University of Michigan, 83, 1-6.

Locke, S. A., Caffara, M., Marcogliese, D. J., \& Fioravanti, M. L. (2015). A large-scale molecular survey of Clinostomum (Digenea, Clinostomidae). Zoologica Scripta, 44, 203-217.

Lorio, W. J. (1989). Experimental control of metacercariae of the yellow grub Clinostomum marginatum in channel catfish. Journal of Aquatic Animal Health, 1, 269-271.

Lunaschi, L. I., \& Drago, F. B. (2009). Digenean parasites of six species of birds from Formosa Province, Argentina. Revista Mexicana de Biodiversidad, 80, 39-46.

McAllister, C. (1990). Metacercaria of Clinostomum complanatum (Rudolphi, 1814) (Trematoda: Digenea) in a Texas salamander, Eurycea neotenes (Amphibia: Caudata), with comments on C. marginatum (Rudolphi, 1819). Journal of the Helminthological Society of Washington, 57, 69-71.

Miller, D. L., Bursey, C. R., Gray, M. J., \& Smith, L. M. (2004). Metacercariae of Clinostomum attenuatum in Ambystoma tigrinum mavortium, Bufo cognatus and Spea multiplicata from west Texas. Journal of Helminthology, 78, 373-376.

Minh, B. Q., Nguyen, M. A. T., \& von Haeseler, A. (2013). Ultrafast approximation for phylogenetic bootstrap. Molecular Biology and Evolution, 30, 1188-1195.
Moraes, J., Silva, M. P. N., Ohlweiler, F. P., \& Kawano, T. (2009). Schistosoma mansoni and other larval trematodes in Biomphalaria tenagophila (Planorbidae) from Guarulhos, São Paulo State, Brazil. Revista do Instituto de Medicina Tropical de São Paulo, 51, 77-82.

Morgan, J. A. T., \& Blair, D. (1998). Relative merits of nuclear ribosomal internal transcribed spacers and mitochondrial CO1 and ND1 genes for distinguishing among Echinostoma species (Trematoda). Parasitology, 116, 289-297.

Nassi, H., \& Bayssade-Dufour, C. (1980). Cycle biologique de Clinostomum golvani n. sp. (Trematoda: Clinostomidae) parasite larvaire de Biomphalaria glabrata, mollusque vecteur de Schistosoma mansoni em Guadalupe. Annales de Parasitologie Humaine et Comparée, 55, 527-540.

Nei, M., \& Kumar, S. (2000). Molecular evolution and phylogenetics. New York: Oxford University Press.

Nguyen, L., Schmidt, H. A., von Haesler, A., \& Minh, B. Q. (2015). IQ-TREE: A fast and effective stochastic algorithm for estimating maximum likelihood phylogenies. Molecular Biology and Evolution, 32, 268-274.

O’Hear, M., Pote, L., Yost, M., Doffitt, C., King, T., \& Panuska, C. (2014). Morphologic and molecular identifications of digenetic trematodes in double-crested cormorants (Phalacrocorax auritus) from the Mississippi Delta, USA. Journal of Wildlife Diseases, 50, 42-49.

Olson, P. D., Cribb, T. H., Tkach, V. V., Bray, R. A., \& Littlewood, D. T. J. (2003). Phylogeny and classification of the Digenea (Platyhelminthes: Trematoda). International Journal for Parasitology, 33, 733-755.

Overstreet, R. M., \& Curran, S. S. (2004). Defeating diplostomoid dangers in USA catfish aquaculture. Folia Parasitologica, 51, 153-165.

Pérez-Ponce de León, G., García-Varela, M., Pinacho-Pinacho, C. D., Sereno-Uribe, A. L., \& Poulin, R. (2016). Species delimitation in trematodes using DNA sequence: MiddleAmerican Clinostomum as a case study. Parasitology, 143, 1773-1789.

Pinto, H. A., Caffara, M., Fioravanti, M. L., \& Melo, A. L. (2015). Experimental and molecular study of cercariae of Clinostomum sp. (Trematoda: Clinostomidae) from Biomphalaria spp. (Mollusca: Planorbidae) in Brazil. Journal of Parasitology, 101, 108-113.

Rosser, T. G., Alberson, N. R., Woodyard, E. T., Cunningham, F. L., Pote, L. M., \& Griffin, M. J. (2017). Clinostomum album n. sp. and Clinostomum marginatum (Rudolphi, 1819), parasites of the great egret Ardea alba L. from Mississippi. USA. Systematic Parasitology, 94, 35-49.

Rosser, T. G., Alberson, N. R., Khoo, L. H., Woodyard, E. T., Pote, L. M., \& Griffin, M. J. (2016a). Characterization of the life cycle of a fish eye fluke, Austrodiplostomum ostrowskiae (Digenea: Diplostomidae), with notes on two other diplostomids infecting Biomphalaria havanensis (Mollusca: Planorbidae) from catfish aquaculture ponds in Mississippi, USA. Journal of Parasitology, 102, 260-274.

Rosser, T. G., Baumgartner, W. A., Alberson, N. R., Woodyard, E. T., Reichley, S. R., Wise, D. J., et al. (2016b). Austrodiplostomum sp., Bolbophorus sp. (Digenea: Diplostomidae), and Clinostomum marginatum (Digenea: Clinostomidae) metacercariae in inland silverside Menidia beryllina from catfish aquaculture ponds, with notes on the infectivity of Austrodiplostomum sp. cercariae in channel 
catfish Ictalurus punctatus. Parasitology Research, 115, 4365-4378.

Ruiz, J. M. (1953). Contribuição ao estudo das formas larvárias de trematódeos brasileiros. 5-Descriçãode três furcocercárias que ocorrem em planorbídeos hospedeiros do Schistosoma mansoni. Memóriasdo Instituto Butantan, 25, 77-89.

Senapin, S., Phiwsaiya, K., Laosinchai, P., Kowasupat, C., Ruenwongsa, P., \& Panijpan, B. (2014). Phylogenetic analysis of parasitic trematodes of the genus Euclinostomum found in Trichopsis and betta fish. Journal of Parasitology, 100, 368-371.

Sereno-Uribe, A. L., Pinacho-Pinacho, C. D., García-Varela, M., \& Pérez-Ponce de León, G. (2013). Using mitochondrial and ribosomal DNA sequences to test the taxonomic validity of Clinostomum complanatum Rudolphi, 1814 in fish-eating birds and freshwater fishes in Mexico, with the description of a new species. Parasitology Research, 112, 2855-2870.

Threlfall, W. (1982). Endoparasites of the double-crested cormorant (Phalacrocorax auritus) in Florida. Proceedings of the Helminthological Society of Washington, 49, 103-108.

Travassos, L., Freitas, J. T., \& Kohn, A. (1969). Trematódeos do Brasil. Memorias do Instituto Oswaldo Cruz, 67, 1-886.
Trifinopoulos, J., Nguyen, L. T., von Haesler, A., \& Minh, B. Q. (2016). W-IQ-TREE: a fast online phylogenetic tool for maximum likelihood analysis. Nucleic Acids Research, 44(W1), W232-W235.

Ukoli, F. M. A. (1966). On Clinostomum tilapiae n. sp., and $C$. phalacrocoracis Dubois, 1931 from Ghana, and a discussion of the systematics of the genus Clinostomum Leidy, 1856. Journal of Helminthology, 40, 187-214.

Vicente, J. J., Santos, E. S., \& Souza, S. V. (1978). Helmintos de peixes de rios amazônicos da Coleção doInstituto Oswaldo Cruz. I. Trematoda. Atas da Sociedade de Biologia do Rio de Janeiro, 25, 9-16.

Wise, D. J., Camus, A., Schwedler, T., \& Terhune, J. (2004). Health management. In: Tucker, C. S. \& Hargreaves J. A. (Eds), Biology and Culture of Channel Catfish. Amsterdam: Elsevier, pp. 482-488.

Woodyard, E. T., Rosser, T. G., \& Rush, S. A. (2017). Alligator wrestling: morphological, molecular, and phylogenetic data on Odhneriotrema incommodum (Leidy, 1856) (Digenea: Clinostomidae) from Alligator mississippiensis Daudin, 1801 in Mississippi, USA. Parasitology Research, 116, 2981-2993. 


\section{Supplementary material for}

Clinostomum poteae $\mathrm{n}$. sp. (Digenea: Clinostomidae), in the trachea of a double-crested cormorant Phalacrocorax auritus Lesson, 1831 and molecular data linking the life-cycle stages of Clinostomum album Rosser, Alberson, Woodyard, Cunningham, Pote \& Griffin, 2017 in Mississippi, USA

Thomas G. Rosser • Wes A. Baumgartner • Neely R. Alberson • Travis W. Noto • Ethan T. Woodyard • D. Tommy King • David J. Wise • Matt J. Griffin

\footnotetext{
T. G. Rosser $(\bowtie) \cdot$ N. R. Alberson • T. W. Noto • E. T. Woodyard Department of Basic Sciences, College of Veterinary Medicine, Mississippi State University, Mississippi 39762, USA email: graham.rosser@msstate.edu
}

\section{W. A. Baumgartner • M. J. Griffin}

Department of Pathobiology and Population Medicine, College of Veterinary Medicine, Mississippi State University, Mississippi State, Mississippi 39762, USA

\section{T. King}

Mississippi Field Station, National Wildlife Research Center, Wildlife Services, United States Department of Agriculture, Mississippi State, Mississippi 39762, USA

\section{J. Griffin • David J. Wise}

${ }^{4}$ Thad Cochran National Warmwater Aquaculture Center, Delta Research and Extension Center, Mississippi State University, Stoneville, Mississippi 38776, USA 
Supplementary Table 1 Primers used in amplification of ribosomal genes and mitochondrial genes of Clinostomum spp. in this study

\begin{tabular}{|c|c|c|c|}
\hline Primer & Sequence $\left(5^{\prime}-3^{\prime}\right)$ & Gene target & Reference \\
\hline $1 \mathrm{~F}$ & TACCTGGTTGATCCTGCCAGTAG & SSU rRNA & Carranza et al. (1997) \\
\hline $5 \mathrm{R}$ & CTTGGCAAATGCTTTCGC & SSU rRNA & Carranza et al. (1997) \\
\hline Barker3 & TTAGAGTGTTCAAAGCAG & SSU rRNA & Barker et al. (1993) \\
\hline Barker4 & GATCCTTCTGCAGGTTCACCTAC & SSU rRNA & Barker et al. (1993) \\
\hline Diplo1795F & CGTCGCTACTACCGATTGAA & SSU rRNA and ITS & Rosser et al. (2016) \\
\hline Diplo2549R & AGTGATCCACCGCTCAGAGT & SSU rRNA and ITS & Rosser et al. (2016) \\
\hline BD1 & GTCGTAACAAGGTTTCCGTA & ITS & Morgan and Blair (1995) \\
\hline BD2 & TATGCTTAAATTCAGCGGGT & ITS & Morgan and Blair (1995) \\
\hline Diplo2617F & CATCGACATCTTGAACGCATA & ITS and 28S rRNA & Rosser et al. (2016) \\
\hline Diplo3170R & GCTGGACTTAGGATGGAGCA & ITS and 28S rRNA & Rosser et al. (2016) \\
\hline LSU5 & TAGGTCGACCCGCTGAAYTTAAGCA & 28S rRNA & Littlewood et al. (2000) \\
\hline 1500R & GCTATCCTGAGGGAAACTTCG & 28S rRNA & Littlewood et al. (2000) \\
\hline $28 \mathrm{~S} 3431 \mathrm{~F}$ & TCAGAGGTAAACGGGTGGAG & 28S rRNA & Rosser et al. (2017) \\
\hline 28S 4779R & CTCAGCTTGCAATGACGGTA & 28S rRNA & Rosser et al. (2017) \\
\hline $28 \mathrm{~S} 4759 \mathrm{~F}$ & GTCTTGAAACACGGACCAAG & 28S rRNA & Rosser et al. (2017) \\
\hline 28S 5699R & TACCACCAAGATCTGCACCT & 28S rRNA & Rosser et al. (2017) \\
\hline Cox1_schist 5, & TCTTTRGATCATAAGCG & $\operatorname{cox} 1$ & Lockyer et al. (2003) \\
\hline Acox650r & CСAAAAAACCAAAACATATGCTG & $\operatorname{cox} 1$ & Kudlai et al. (2015) \\
\hline NDJ11 & AGATTCGTAAGGGGCCTAATA & $n d 1$ & Morgan and Blair (1998) \\
\hline NDJ $2 \mathrm{a}$ & CTTCAGCCTCAGCATAAT & $n d 1$ & Kostadinova et al. (2003) \\
\hline
\end{tabular}




\section{References}

Carranza, S., Baguña, J., \& Riutort, M. (1997). Are the Platyhelminthes a monophyletic primitive group? An assessment using 18S rDNA sequences. Molecular Biology and Evolution, 14, 495-497.

Barker, S. C., Blair, D., Cribb, T. H., \& Tonion, K. (1993). Phylogenetic position of Heronimus mollis (Digenea): Evidence from 18S ribosomal RNA. International Journal for Parasitology, 23, 533-536.

Kudlai, O., Kostadinova, A., Pulis, E. E., \& Tkach, V. V. (2015). A new species of Drepanocephalus Dietz, 1909 (Digenea: Echinostomatidae) from the double-crested cormorant Phalacrocorax auritus (Lesson) (Aves: Phalacrocoracidae) in North America. Systematic Parasitology, 90, 221-230.

Littlewood, D. T. J., Curini-Galletti, M., \& Herniou, E. A. (2000). The interrelationships of Proseriata (Platyhelminthes: Seratia) flatworms tested with molecules and morphology. Molecular Phylogenetics and Evolution, 16, 449-466.

Lockyer, A. E., Olson, P. D., Ostergaard, P., Rollinson, D., Johnston, D. A., Attwood, S. W., et al. (2003). The phylogeny of the Schistosomatidae based on three genes with emphasis on the interrelationships of Schistosoma Weinland, 1858. Parasitology, 126, 203-224.

Morgan, J. A. T., \& Blair, D. (1995). Nuclear rDNA ITS sequence variation in the trematode genus Echinostoma: An aid to establishing relationships within the 37-collar spine group. Parasitology, 111, 609-615.

Morgan, J. A. T., \& Blair, D. (1998). Relative merits of nuclear ribosomal internal transcribed spacers and mitochondrial CO1 and ND1 genes for distinguishing among Echinostoma species (Trematoda). Parasitology, 116, 289-297.

Rosser, T. G., Alberson, N. R., Khoo, L. H., Woodyard, E. T., Pote, L. M., \& Griffin, M. J. (2016). Characterization of the life cycle of a fish eye fluke, Austrodiplostomum ostrowskiae (Digenea: Diplostomidae), with notes on two other diplostomids infecting Biomphalaria havanensis (Mollusca: Planorbidae) from catfish aquaculture ponds in Mississippi, USA. Journal of Parasitology, 102, 260-274.

Rosser, T. G., Alberson, N. R., Woodyard, E. T., Cunningham, F. L., Pote, L. M., \& Griffin, M. J. (2017). Clinostomum album n. sp. and Clinostomum marginatum (Rudolphi, 1819), parasites of the great egret Ardea alba L. from Mississippi, USA. Systematic Parasitology, 94, 35-49. 
Supplementary Table 2 Sequences used in phylogenetic analyses

\begin{tabular}{|c|c|c|c|c|c|c|c|}
\hline Species & \multirow{2}{*}{\multicolumn{2}{|c|}{$\begin{array}{l}\text { Genbank Accession No. } \\
\text { ITS } \\
\end{array}$}} & Isolate & Host & Stage & Locality & Reference \\
\hline & & & & & & & \multirow{6}{*}{$\begin{array}{l}\text { Rosser et al. } 2017 \\
\text { Caffara et al. } \\
2011 \\
\text { Caffara et al. } \\
2011 \\
\text { Locke et al. } 2015 \\
\text { Caffara et al. } \\
2011\end{array}$} \\
\hline Clinostomum album & KU708008 & KU708010 & $\mathrm{C}-2$ & Ardea alba & A & Mississippi, USA & \\
\hline Clinostomum attenuatum & JF718622 & JF718587 & C.M.Rp.1.1 & Lithobates pipiens & M & Canada & \\
\hline Clinostomum attenuatum & JF718620 & JF718585 & Cm.Rcl.BBA8.1.1 & Lithobates clamitans & M & Quebec, Canada & \\
\hline $\begin{array}{l}\text { Clinostomum attenuatum } \\
\text { Clinostomum }\end{array}$ & KP150307 & KP150305 & CL.Bc.R.p.VPH.1.1 & Lithobates pipiens & $\mathrm{M}$ & USA & \\
\hline $\begin{array}{l}\text { marginatum } \\
\text { Clinostomum }\end{array}$ & JF718634 & JF718600 & Cl.RM.B08.P.1F.2 & Perca flavescens & M & Quebec, Canada & \\
\hline $\begin{array}{l}\text { marginatum } \\
\text { Clinostomum }\end{array}$ & MH282555 & KU707946 & Cm_1-C-1 & Menidia beryllina & M & Mississippi, USA & \multirow{3}{*}{$\begin{array}{l}\text { Rosser et al. } 2016 \\
\text { Caffara et al. } \\
2011 \\
\text { Caffara et al. } \\
2011\end{array}$} \\
\hline marginatum & JF718636 & JF718604 & Cl.GRI.Ah.1F.3 & Ardea herodias & A & Quebec, Canada & \\
\hline $\begin{array}{l}\text { Clinostomum } \\
\text { marginatum } \\
\text { Clinostomum }\end{array}$ & JF718635 & JF718602 & Cl.GRI.Ah.1F.1 & Ardea herodias & A & Quebec, Canada & \\
\hline $\begin{array}{l}\text { marginatum } \\
\text { Clinostomum }\end{array}$ & KU708007 & KU708009 & $\mathrm{C}-1$ & Ardea alba & A & Mississippi, USA & \multirow{2}{*}{$\begin{array}{l}\text { Rosser et al. } 2017 \\
\text { Caffara et al. } \\
2011\end{array}$} \\
\hline $\begin{array}{l}\text { marginatum } \\
\text { Clinostomum }\end{array}$ & JF718640 & JF718612 & Cl.RON.B.S.1.1 & Lepomis gibbosus & M & Quebec, Canada & \\
\hline $\begin{array}{l}\text { marginatum } \\
\text { Clinostomum }\end{array}$ & MH282554 & MH282538 & Cm_Lm_1 & Lepomis macrochirus & M & Mississippi, USA & \multirow{5}{*}{$\begin{array}{l}\text { This study } \\
\text { Caffara et al. } \\
2011 \\
\text { Caffara et al. } \\
2011 \\
\text { Caffara et al. } \\
2011 \\
\text { Caffara et al. } \\
2011\end{array}$} \\
\hline $\begin{array}{l}\text { marginatum } \\
\text { Clinostomum }\end{array}$ & JF718641 & JF718615 & Cl.RM.D.P.18.1 & Perca flavescens & $\mathrm{M}$ & Quebec, Canada & \\
\hline $\begin{array}{l}\text { marginatum } \\
\text { Clinostomum }\end{array}$ & JF718633 & JF718599 & Cm.M.2.R.5.2 & Ambloplites rupestris & M & Quebec, Canada & \\
\hline $\begin{array}{l}\text { marginatum } \\
\text { Clinostomum }\end{array}$ & JF718632 & JF718598 & Cm.M.2.R.5.1 & Ambloplites rupestris & $\mathrm{M}$ & Quebec, Canada & \\
\hline marginatum & JF718631 & JF718597 & Cl.LM.B08.Ms.1F.3 & Micropterus salmoides & M & Quebec, Canada & \\
\hline Clinostomum poteae & MH282567 & MH282550 & R02-Clino-1 & Phalacrocorax auritus & A & Mississippi, USA & This study \\
\hline Clinostomum poteae & MH282568 & MH282551 & R02-Clino-2 & Phalacrocorax auritus & A & Mississippi, USA & This study \\
\hline Clinostomum poteae & MH282569 & MH282552 & R02-Clino-3 & Phalacrocorax auritus & A & Mississippi, USA & This study \\
\hline Clinostomum poteae & MH282570 & MH282553 & R02-Clino-4 hologenophore & Phalacrocorax auritus & A & Mississippi, USA & This study \\
\hline
\end{tabular}


Clinostomum album

Clinostomum album

Clinostomum album

Clinostomum album

Clinostomum album

Clinostomum album

Clinostomum album

Clinostomum album

Clinostomum album

Clinostomum album

Clinostomum album

Clinostomum tataxuтui

Clinostomum tataxumui

Clinostomum tataxumui

Clinostomum tataxumui

Clinostomum tataxumui

Clinostomum tataxumui

Clinostomum tataxumui

Clinostomum tataxumui

Clinostomum tataxumui

Clinostomum sp. 5 SAL-

2015

Clinostomum sp. 5 SAL-

2015

Clinostomum sp. 1 SAL-

2015

Clinostomum sp. 3 SAL-

2015

Clinostomum sp. 4 SAL-

2015

$\begin{array}{lll}\text { MH282566 } & \text { MH282549 } & \text { Ca_Pt_1 } \\ \text { MH282565 } & \text { MH282548 } & \text { Ca_Pt_2 } \\ \text { MH282564 } & \text { MH282547 } & \text { Ca_Pt_3 } \\ \text { MH282563 } & \text { MH282546 } & \text { Ca_Pt_4 } \\ \text { MH282562 } & \text { MH282545 } & \text { Ca_Pt_5 } \\ \text { MH282561 } & \text { MH282544 } & \text { Ca_Pt_6 } \\ \text { MH282560 } & \text { MH282543 } & \text { Ca_Pt_7 } \\ \text { MH282559 } & \text { MH282542 } & \text { Ca_Pt_8 } \\ \text { MH282558 } & \text { MH282541 } & \text { Ca_Pt_9 } \\ \text { MH282557 } & \text { MH282540 } & \text { Ca_Pt_10 } \\ \text { MH282556 } & \text { MH282539 } & \text { Ca_Pp_1 } \\ \text { KP110588 } & \text { KP110544 } & \text { C.BC.Ep.TRP4 } \\ \text { KP110593 } & \text { KP110559 } & \text { C.BC.DI.TRP.1 } \\ \text { KP110590 } & \text { KP110546 } & \text { C.BC.Ct.TRP2 } \\ \text { KP110597 } & \text { KP110563 } & \text { C.BC.Ep.TRP3 } \\ \text { KP110596 } & \text { KP110562 } & \text { C.BC.Ep.TRP2 } \\ \text { KP110595 } & \text { KP110561 } & \text { C.BC.Ep.TRP1 } \\ \text { KP110592 } & \text { KP110551 } & \text { C.LV.Vent.1.4 } \\ \text { KP110591 } & \text { KP110550 } & \text { C.LV.P.Vent.1.1 } \\ \text { KP110594 } & \text { KP110560 } & \text { C.BC.DI.TRP.2 } \\ & & \\ \text { KP110576 } & \text { KP110533 } & \text { C.G.Cb.SCR.4.a } \\ & & \\ \text { KP110575 } & \text { KP110532 } & \text { C.Oes.Cb.SCR.4.c } \\ \text { KP110571 } & \text { KP110524 } & \text { Cl.Rg.CIH.X.1 } \\ \text { KP110573 } & \text { KP110530 } & \text { C.G.Pm.ABA.X.1 } \\ \text { KP110574 } & \text { KP110531 } & \text { C.Asp.ITA.1.1 } \\ \text { KP110577 } & \text { KP110534 } & \text { C.F.Cb.SCR.4.b } \\ \text { KJ789385 } & \text { KJ818259 } & \text { 43/13_1 } \\ \text { KJ789386 } & \text { KJ818261 } & \text { 43/13_2 } \\ \text { 43/13_3 }\end{array}$

Planorbella trivolvis

Planorbella trivolvis

Planorbella trivolvis

Planorbella trivolvis

Planorbella trivolvis

Planorbella trivolvis

Planorbella trivolvis

Planorbella trivolvis

Planorbella trivolvis

Planorbella trivolvis

Pimephales promelas

Eleotris picta

Dormitator latifrons

Cichlasoma trimaculatum

Eleotris picta

Eleotris picta

Eleotris picta

Gobiomorus maculatus

Dormitator latifrons

Dormitator latifrons

Cichlasoma boliviense

Cichlasoma boliviense

Rhamdia guatamalensis

Poecilia mexicana

Apistogramma sp.

Cichlasoma boliviense

Poecilia reticulata

Poecilia reticulata

Poecilia reticulata
Mississippi, USA

Mississippi, USA

Mississippi, USA

Mississippi, USA

Mississippi, USA

Mississippi, USA

Mississippi, USA

Mississippi, USA

Mississippi, USA

Mississippi, USA

Mississippi, USA

Guerrero, Mexico

Guerrero, Mexico

Guerrero, Mexico

Guerrero, Mexico

Guerrero, Mexico

Guerrero, Mexico

Oaxaca, Mexico

Oaxaca, Mexico

Guerrero, Mexico

Santa Cruz, Bolivia

Santa Cruz, Bolivia

Yucatan, Mexico

Veracruz, Mexico

Iquitos, Peru

Santa Cruz, Bolivia

Brazil

Brazil

Brazil
This study

This study

This study

This study

This study

This study

This study

This study

This study

This study

This study

Locke et al. 2015

Locke et al. 2015

Locke et al. 2015

Locke et al. 2015

Locke et al. 2015

Locket et al. 2015

Locke et al. 2015

Locke et al. 2015

Locke et al. 2015

Locke et al. 2015

Locke et al. 2015

Locke et al. 2015

Locke et al. 2015

Locke et al. 2015

Locke et al. 2015

Pinto et al. 2015

Pinto et al. 2015

Pinto et al. 2015 


\begin{tabular}{|c|c|c|c|}
\hline $\begin{array}{l}\text { Clinostomum } \\
\text { detruncatum }\end{array}$ & KP110566 & KP110517 & C.Sm.ITA.1.1 \\
\hline $\begin{array}{l}\text { Clinostomum } \\
\text { phalacrocoracis }\end{array}$ & KJ786979 & KJ786971 & 20/13_B1 \\
\hline $\begin{array}{l}\text { Clinostomum } \\
\text { phalacrocoracis }\end{array}$ & KJ786975 & KJ786967 & 20/13_A1 \\
\hline $\begin{array}{l}\text { Clinostomum } \\
\text { phalacrocoracis } \\
\text { Clinostomum }\end{array}$ & KJ786976 & KJ786968 & 20/13_A2 \\
\hline $\begin{array}{l}\text { phalacrocoracis } \\
\text { Clinostomum }\end{array}$ & KP110567 & KP110521 & Cp.On.KYA.X.1 \\
\hline $\begin{array}{l}\text { phalacrocoracis } \\
\text { Clinostomum }\end{array}$ & KJ786982 & KJ786974 & 20/13_B7 \\
\hline $\begin{array}{l}\text { phalacrocoracis } \\
\text { Clinostomum }\end{array}$ & KJ786981 & KJ786973 & 20/13_B3 \\
\hline $\begin{array}{l}\text { phalacrocoracis } \\
\text { Clinostomum }\end{array}$ & KJ786980 & KJ786972 & 20/13_B2 \\
\hline $\begin{array}{l}\text { phalacrocoracis } \\
\text { Clinostomum }\end{array}$ & KP110568 & KP110522 & Cp.O.Ac.KYA.X.1 \\
\hline $\begin{array}{l}\text { phalacrocoracis } \\
\text { Clinostomum }\end{array}$ & KJ786977 & KJ786969 & 20/13_A3 \\
\hline phalacrocoracis & KJ786978 & KJ786970 & 20/13_A7 \\
\hline Clinostomum tilapiae & KY649353 & KY649361 & $172 / 15 \_7$ \\
\hline Clinostomum tilapiae & KY649355 & KY649363 & 172/15_21 \\
\hline Clinostomum tilapiae & KY649356 & KY649364 & 172/15_22 \\
\hline Clinostomum tilapiae & KY649349 & KY649357 & 172/15_A1 \\
\hline Clinostomum tilapiae & KY649350 & KY649358 & 172/15_A2 \\
\hline Clinostomum tilapiae & KY649352 & KY649360 & 172/15_B1 \\
\hline Clinostomum tilapiae & KY649351 & KY649359 & 172/15_A3 \\
\hline Clinostomum tilapiae & KY649354 & KY649362 & 172/15_20 \\
\hline Clinostomum cutaneum & KP110565 & KP110516 & Cc.On.KYA.X.1 \\
\hline
\end{tabular}

\begin{tabular}{|c|c|c|c|}
\hline Synbranchus marmoratus & M & Parana, Brazil & $\begin{array}{l}\text { Locke et al. } 2015 \\
\text { Caffara et al. }\end{array}$ \\
\hline Cichlid fingerling & $\mathrm{M}$ & Israel & 2014 \\
\hline Cichlid fingerling & $\mathrm{M}$ & Israel & $\begin{array}{l}\text { Caffara et al. } \\
2014 \\
\text { Caffara et al. }\end{array}$ \\
\hline $\begin{array}{l}\text { Cichlid fingerling } \\
\text { Oreochromis niloticus }\end{array}$ & $\mathrm{M}$ & Israel & 2014 \\
\hline niloticus & $\mathrm{M}$ & Kenya & $\begin{array}{l}\text { Locke et al. } 2015 \\
\text { Caffara et al. }\end{array}$ \\
\hline Cichlid fingerling & $\mathrm{M}$ & Israel & $\begin{array}{l}2014 \\
\text { Caffara et al. }\end{array}$ \\
\hline Cichlid fingerling & $\mathrm{M}$ & Israel & $\begin{array}{l}2014 \\
\text { Caffara et al. }\end{array}$ \\
\hline Cichlid fingerling & $\mathrm{M}$ & Israel & 2014 \\
\hline Ardea cinerea & $\mathrm{A}$ & Kenya & $\begin{array}{l}\text { Locke et al. } 2015 \\
\text { Caffara et al. }\end{array}$ \\
\hline Cichlid fingerling & $\mathrm{M}$ & Israel & $\begin{array}{l}2014 \\
\text { Caffara et al. }\end{array}$ \\
\hline Cichlid fingerling & $\mathrm{M}$ & Israel & $\begin{array}{l}2014 \\
\text { Caffara et al. }\end{array}$ \\
\hline Synodontis batensoda & $\mathrm{M}$ & Nigeria & $\begin{array}{l}2017 \\
\text { Caffara et al. }\end{array}$ \\
\hline Synodontis batensoda & $\mathrm{M}$ & Nigeria & $\begin{array}{l}2017 \\
\text { Caffara et al. }\end{array}$ \\
\hline Synodontis batensoda & $\mathrm{M}$ & Nigeria & $\begin{array}{l}2017 \\
\text { Caffara et al. }\end{array}$ \\
\hline Synodontis batensoda & $\mathrm{M}$ & Nigeria & $\begin{array}{l}2017 \\
\text { Caffara et al. }\end{array}$ \\
\hline Synodontis batensoda & $\mathrm{M}$ & Nigeria & $\begin{array}{l}2017 \\
\text { Caffara et al. }\end{array}$ \\
\hline Synodontis batensoda & $\mathrm{M}$ & Nigeria & $\begin{array}{l}2017 \\
\text { Caffara et al. }\end{array}$ \\
\hline Synodontis batensoda & $\mathrm{M}$ & Nigeria & $\begin{array}{l}2017 \\
\text { Caffara et al. }\end{array}$ \\
\hline $\begin{array}{l}\text { Synodontis batensoda } \\
\text { Oreochromis niloticus }\end{array}$ & $\mathrm{M}$ & Nigeria & 2017 \\
\hline niloticus & $\mathrm{M}$ & Kenya & Locke et al. 2015 \\
\hline
\end{tabular}




\begin{tabular}{|c|c|c|c|c|c|c|c|}
\hline $\begin{array}{l}\text { Clinostomum cutaneum } \\
\text { Clinostomum }\end{array}$ & KP110564 & KP110515 & Cc.Ac.KYA.X.1 & Ardea cinerea & A & Kenya & Locke et al. 2015 \\
\hline $\begin{array}{l}\text { philippinense } \\
\text { Clinostomum sp. } 8 \text { SAL- }\end{array}$ & KP110570 & KP110523 & C.Tm.ITA.1.2 & Trichogaster microlepis & M & Thailand & Locke et al. 2015 \\
\hline $\begin{array}{l}2015 \\
\text { Clinostomum sp. } 8 \text { SAL- }\end{array}$ & KP110583 & KP110539 & C.G.Ca.CHU.4.1 & Carassius auritus & $\mathrm{M}$ & Hubei, China & Locke et al. 2015 \\
\hline $\begin{array}{l}2015 \\
\text { Clinostomum sp. } 8 \text { SAL- }\end{array}$ & KP110580 & KP110536 & C.Op.Ca.Lzi.3 & Carassius auritus & $\mathrm{M}$ & Hubei, China & Locke et al. 2015 \\
\hline $\begin{array}{l}2015 \\
\text { Clinostomum sp. } 8 \text { SAL- }\end{array}$ & KP110581 & KP110537 & C.Op.Ca.Lzi.4 & Carassius auritus & M & Hubei, China & Locke et al. 2015 \\
\hline $\begin{array}{l}2015 \\
\text { Clinostomum sp. } 8 \text { SAL- }\end{array}$ & KP110585 & KP110541 & C.Op.Ci.HUB.1 & Ctenopharyngodon idella & $\mathrm{M}$ & Hubei, China & Locke et al. 2015 \\
\hline $\begin{array}{l}2015 \\
\text { Clinostomum sp. } 8 \text { SAL- }\end{array}$ & KP110582 & KP110538 & C.Op.Ca.Lzi.5 & Carassius auritus & M & Hubei, China & Locke et al. 2015 \\
\hline $\begin{array}{l}2015 \\
\text { Clinostomum sp. } 8 \text { SAL- }\end{array}$ & KP110586 & KP110542 & C.Op.Ca.Lzi.1 & Carassius auritus & M & Hubei, China & Locke et al. 2015 \\
\hline $\begin{array}{l}2015 \\
\text { Clinostomum }\end{array}$ & KP110579 & KP110535 & C.Op.Ci.HUB.2 & Ctenopharyngodon idella & M & Hubei, China & $\begin{array}{l}\text { Locke et al. } 2015 \\
\text { Caffara et al. }\end{array}$ \\
\hline $\begin{array}{l}\text { complanatum } \\
\text { Clinostomum }\end{array}$ & JF718624 & JF718589 & C.S.ITA5.1 & $\begin{array}{l}\text { Lepomis gibbosus } \\
\text { Newts: Triturus carnifex, }\end{array}$ & $\mathrm{M}$ & Veneto, Italy & 2011 \\
\hline complanatum & KM518258 & KM518252 & $228 / 11 \_2$ & Lissotriton vulgaris & M & $\begin{array}{l}\text { Italy } \\
\text { Emilia-Romagna, }\end{array}$ & $\begin{array}{l}2014 \\
\text { Caffara et al. }\end{array}$ \\
\hline $\begin{array}{l}\text { complanatum } \\
\text { Clinostomum }\end{array}$ & JF718623 & JF718588 & C.Sc.ITA3.6 & $\begin{array}{l}\text { Squalius cephalus } \\
\text { Newts: Triturus carnifex, }\end{array}$ & M & Itay & $\begin{array}{l}2011 \\
\text { Caffara et al. }\end{array}$ \\
\hline $\begin{array}{l}\text { complanatum } \\
\text { Euclinostomum }\end{array}$ & KM518259 & KM518253 & $228 / 11 \_1$ & Lissotriton vulgaris & $\mathrm{M}$ & Italy & $\begin{array}{l}2014 \\
\text { Caffara et al. }\end{array}$ \\
\hline $\begin{array}{l}\text { heterostomum } \\
\text { Euclinostomum }\end{array}$ & KР721427 & KР721409 & 349/13_7 & Cichlids & M & Israel & $\begin{array}{l}2016 \\
\text { Caffara et al. }\end{array}$ \\
\hline $\begin{array}{l}\text { heterostomum } \\
\text { Euclinostomum }\end{array}$ & KР721434 & KP721416 & 55/14_7 & Cichlids & M & Israel & $\begin{array}{l}2016 \\
\text { Caffara et al. }\end{array}$ \\
\hline $\begin{array}{l}\text { heterostomum } \\
\text { Euclinostomum }\end{array}$ & KP721435 & KP721417 & 55/14_8 & Cichlids & M & Israel & 2016 \\
\hline $\begin{array}{l}\text { heterostomum } \\
\text { Euclinostomum }\end{array}$ & KP721429 & KP721412 & 55/14_2 & Cichlids & $\mathrm{M}$ & Israel & 2016 \\
\hline $\begin{array}{l}\text { heterostomum } \\
\text { Euclinostomum }\end{array}$ & KP721424 & KP721406 & 349/13_4 & Cichlids & M & Israel & $\begin{array}{l}2016 \\
\text { Caffara et al. }\end{array}$ \\
\hline heterostomum & KP721436 & KP721418 & 55/14_9 & Cichlids & $\mathrm{M}$ & Israel & 2016 \\
\hline $\begin{array}{l}\text { Euclinostomum } \\
\text { heterostomum }\end{array}$ & KP721423 & KP721405 & 349/13_3 & Cichlids & $\mathrm{M}$ & Israel & $\begin{array}{l}\text { Caffara et al. } \\
2016\end{array}$ \\
\hline
\end{tabular}




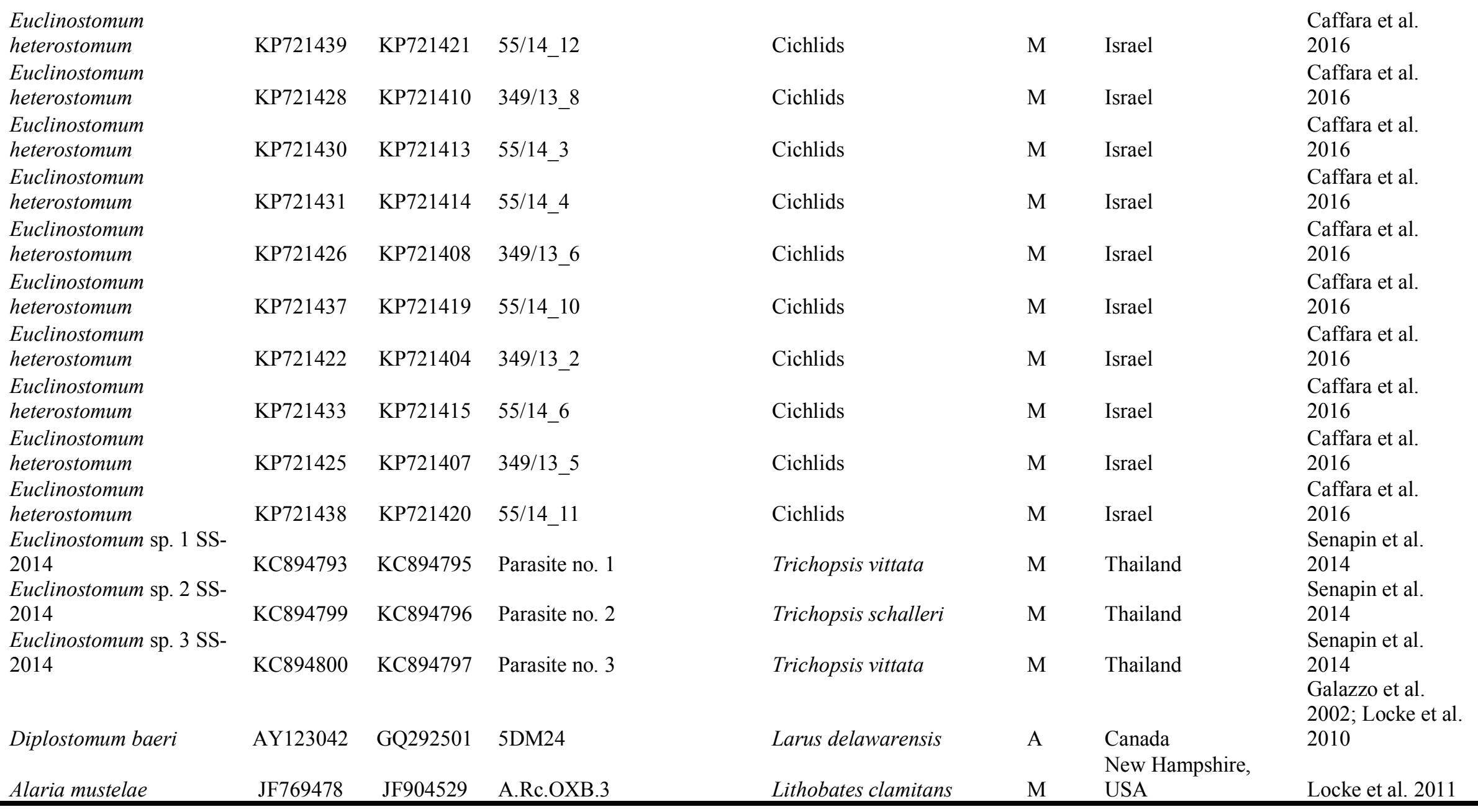

Abbreviations: A, adult; C, cercaria; M, metacercaria 


\section{References}

Caffara, M., Bruni, G., Paoletti, C., Gustinelli, A., \& Fioravanti, M. L. (2014a). Metacercariae of Clinostomum complanatum (Trematoda: Digenea) in European newts Triturus carnifex and Lissotriton vulgaris (Caudata: Salamandridae). Journal of Helminthology, 88, 278-285.

Caffara, M., Davidovich, N., Falk, R., Smirnov, M., Ofek, T., Cummings, D., Gustinelli, A., \& Fioravanti, M. L. (2014b). Redescription of Clinostomum phalacrocoracis metacercariae (Digenea: Clinostomidae) in cichlids from Lake Kinneret, Israel. Parasite, 21, 32.

Caffara, M., Locke, S. A., Cristanini, C., Davidovich, N., Markovich, M. P., \& Fioravanti, M. L. (2016). A combined morphometric and molecular approach to identifying metacercariae of Euclinostomum heterostomum (Digenea: Clinostomidae). Journal of Parasitology, 102, 239248.

Caffara, M., Locke, S. A., Echi, P. C., Halajian, A., Benini, D., Luus-Powell, W. J., Tavakol, S., \& Fioravanti, M. L. (2017). A morphological and molecular study of clinostomid metacercariae from African fish with a redescription of Clinostomum tilapiae. Parasitology, 144, 1519-1529.

Caffara, M., Locke, S. A., Gustinelli, A., Marcogliese, D. J., \& Fioravanti, M. L. (2011). Morphological and molecular differentiation of Clinostomum complanatum and Clinostomum marginatum (Digenea: Clinostomidae) metacercariae and adults. Journal of Parasitology, 97, 884-891.

Galazzo, D. E., Dayanandan, S., Marcogliese, D. J., \& McLaughlin, J. D. (2002). Molecular systematics of some North American species of Diplostomum (Digenea) based on rDNAsequence data and comparisons with European congeners. Canadian Journal of Zoology, 80, $2207-2217$.

Locke, S. A., Caffara, M., Marcogliese, D. J., \& Fioravanti, M. L. (2015). A large-scale molecular survey of Clinostomum (Digenea, Clinostomidae). Zoologica Scripta, 44, 203-217.

Locke, S. A., McLaughlin, J. D., Dayanandan, S., \& Marcogliese, D. J. (2010). Diversity and specificity in Diplostomum spp. metacercariae in freshwater fishes revealed by cytochrome $c$ oxidase I and internal transcribed spacer sequences. International Journal for Parasitology, 40, 333-343.

Locke, S. A., McLaughlin, J. D., Lapierre, A. R., Johnson, P. T., \& Marcogliese, D. J. (2011). Linking larvae and adults of Apharyngostrigea cornu, Hysteromorpha triloba, and Alaria mustelae (Diplostomoidea: Digenea) using molecular data. Journal of Parasitology, 97, 846851. 
Pinto, H. A., Caffara, M., Fioravanti, M. L., \& Melo, A. L. (2015). Experimental and molecular study of cercariae of Clinostomum sp. (Trematoda: Clinostomidae) from Biomphalaria spp. (Mollusca: Planorbidae) in Brazil. Journal of Parasitology, 101, 108-113.

Rosser, T. G., Baumgartner, W. A., Alberson, N. R., Woodyard, E. T., Reichley, S. R., Wise, D. J., Pote, L. M., \& Griffin, M. J. (2016). Austrodiplostomum sp., Bolbophorus sp. (Digenea: Diplostomidae), and Clinostomum marginatum (Digenea: Clinostomidae) metacercariae in inland silverside Menidia beryllina from catfish aquaculture ponds, with notes on the infectivity of Austrodiplostomum sp. cercariae in channel catfish Ictalurus punctatus. Parasitology Research, 115, 4365-4378.

Rosser, T. G., Alberson, N. R., Woodyard, E. T., Cunningham, F. L., Pote, L. M., Griffin, M. J. (2017). Clinostomum album n. sp. and Clinostomum marginatum (Rudolphi, 1819), parasites of the great egret Ardea alba L. from Mississippi, USA. Systematic Parasitology, 94, 35-49. Senapin, S., Phiwsaiya, K., Laosinchai, P., Kowasupat, C., Ruenwongsa, P., \& Panijpant, B. (2014). Phylogenetic analysis of parasitic trematodes of the genus Euclinostomum found in Trichopsis and Betta fish. Journal of Parasitology, 100, 368-371. 
Supplementary Table 3 Morphological data of Clinostomum spp. redia from aquatic snails in the Americas

\begin{tabular}{|c|c|c|c|c|}
\hline & $\begin{array}{c}\text { Clinostomum } \\
\text { album }\end{array}$ & Clinostomum sp. & $\begin{array}{l}\text { Clinostomum } \\
\text { golvani }\end{array}$ & $\begin{array}{l}\text { Clinostomum } \\
\text { marginatum }\end{array}$ \\
\hline Host & $\begin{array}{c}\text { Planorbella } \\
\text { trivolvis }\end{array}$ & $\begin{array}{l}\text { Biomphalaria } \\
\text { glabrata, } \\
\text { Biomphalaria } \\
\text { straminea, } \\
\text { Biomphalaria } \\
\text { tenagophila }\end{array}$ & $\begin{array}{l}\text { Biomphalaria } \\
\text { glabrata }\end{array}$ & Planorbella anceps \\
\hline Locality & $\begin{array}{l}\text { Mississippi, } \\
\text { USA }\end{array}$ & $\begin{array}{c}\text { Minas Gerais, } \\
\text { Brazil }\end{array}$ & $\begin{array}{l}\text { Guadelopue, West } \\
\text { Indies }\end{array}$ & Maryland, USA \\
\hline Reference & This study & Pinto et al. (2015) & $\begin{array}{l}\text { Nassi \& Bayssade- } \\
\text { Dufour (1980) }\end{array}$ & Krull 1934* \\
\hline$\overline{\mathrm{BL}}$ & $\begin{array}{c}271-819 \\
(455)\end{array}$ & $\begin{array}{c}* 1375-2321 \\
(1826)\end{array}$ & $2000-3100$ & $\overline{490}$ \\
\hline BW & $\begin{array}{l}97-235 \\
(150)\end{array}$ & $\begin{array}{c}150-205 \\
(177)\end{array}$ & - & 140 \\
\hline $\mathrm{PhL}$ & $\begin{array}{c}30-57 \\
(47)\end{array}$ & $\begin{array}{c}38-50 \\
(46)\end{array}$ & 67 & 36 \\
\hline $\mathrm{PhW}$ & $\begin{array}{c}31-58 \\
(46)\end{array}$ & $\begin{array}{c}42-53 \\
(46)\end{array}$ & - & 27 \\
\hline $\mathrm{CL}$ & $\begin{array}{c}162-523 \\
(291)\end{array}$ & $\begin{array}{c}683-1203 \\
(878)\end{array}$ & $\begin{array}{c}2 / 3-4 / 5 \text { body } \\
\text { length }\end{array}$ & - \\
\hline $\mathrm{CW}$ & $\begin{array}{c}28-59 \\
(41)\end{array}$ & $\begin{array}{c}25-47 \\
(30)\end{array}$ & - & - \\
\hline
\end{tabular}

Abbreviations: BL, body length; BW, body width; PhL, pharynx length; PhW, pharynx width; $\mathrm{CL}$, caecum length; $\mathrm{CW}$, caecum width.

*Measurements from the single largest redia.

\section{References}

Krull, W. H. (1934). Some observations on the cercaria and redia of a species of Clinostomum, apparently C. marginatum (Rudolphi, 1819) (Trematoda: Clinostomidae). Proceedings of the Helminthological Society of Washington, 1, 34-35.

Nassi H., \& Bayssade-Dufour C. (1980). Cycle biologique de Clinostomum golvani n. sp. (Trematoda: Clinostomidae) parasite larvaire de Biomphalaria glabrata, mollusque vecteur de Schistosoma mansoni em Guadalupe. Annales de Parasitologie, 55, 527-540. 
Pinto, H. A., Caffara, M., Fioravanti, M. L., \& Melo, A. L. (2015). Experimental and molecular study of cercariae of Clinostomum sp. (Trematoda: Clinostomidae) from Biomphalaria spp. (Mollusca: Planorbidae) in Brazil. Journal of Parasitology, 101, 108-113. 
Supplementary Figure 1. Clinostomum poteae n. sp. hologenophore. Mayer's carmalum stain. Scale bar: $1 \mathrm{~mm}$.

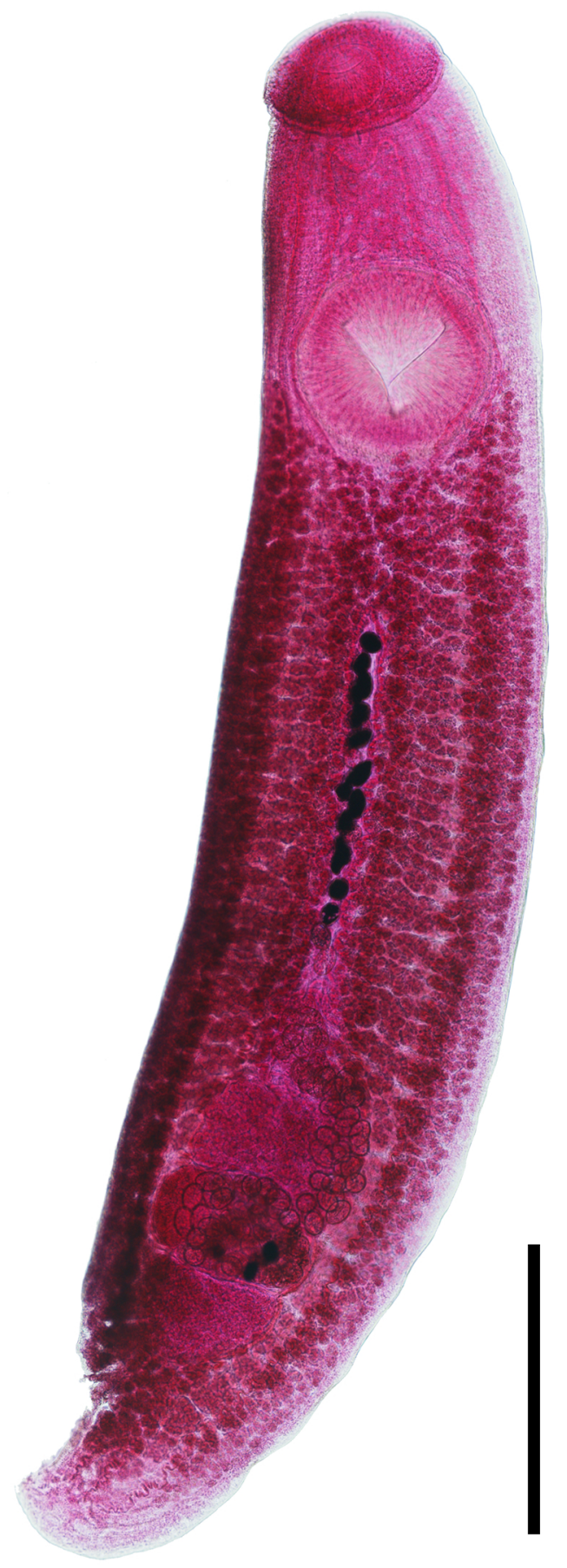


Supplementary Figure 2. Clinostomum marginatum hologenophore from bluegill Lepomis macrochirus. Mayer's carmalum stain. Scale bar: $1 \mathrm{~mm}$.

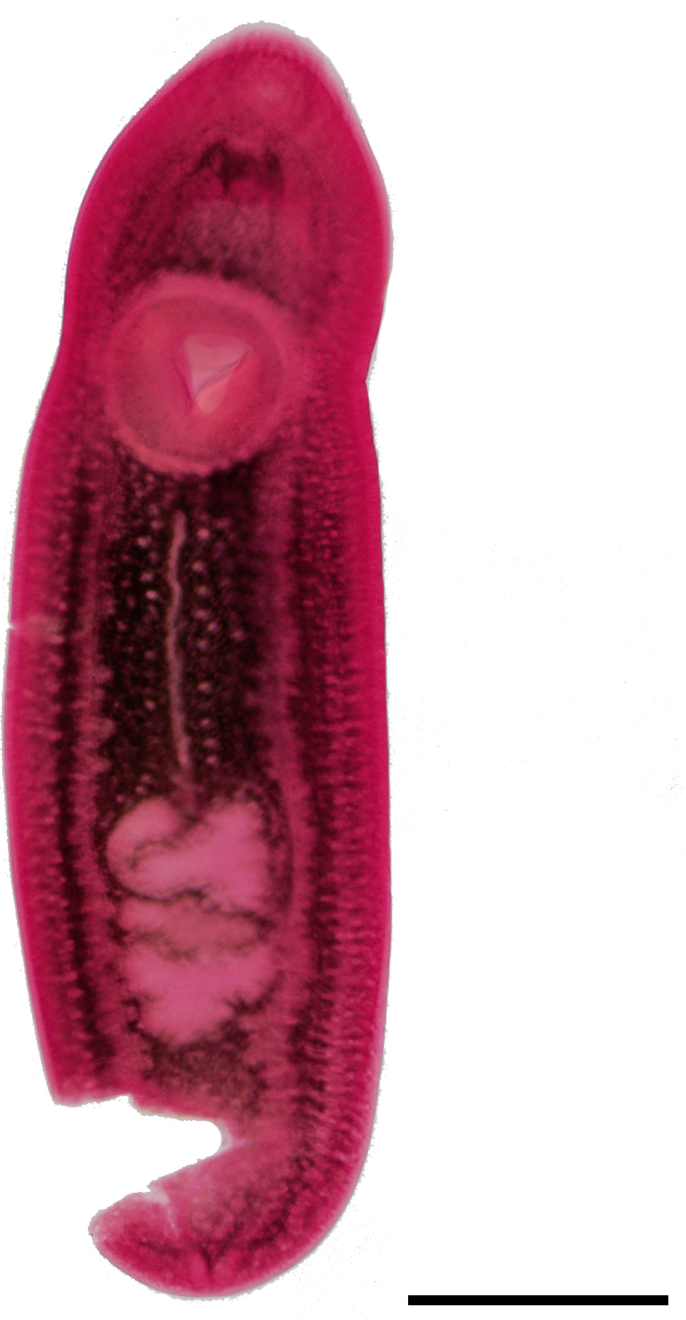


Supplementary Figure 3. Phylogenetic tree constructed from concatenated cox 1 gene and ITS regions alignment. Numbers above the branches represent Bayesian posterior probabilities and maximum likelihood bootstrap values based on 1,000 pseudoreplicates $(<0.5$ are not shown). Clinostomum species obtained in this study are in bold. Scale-bar: average number of nucleotide substitutions per site.

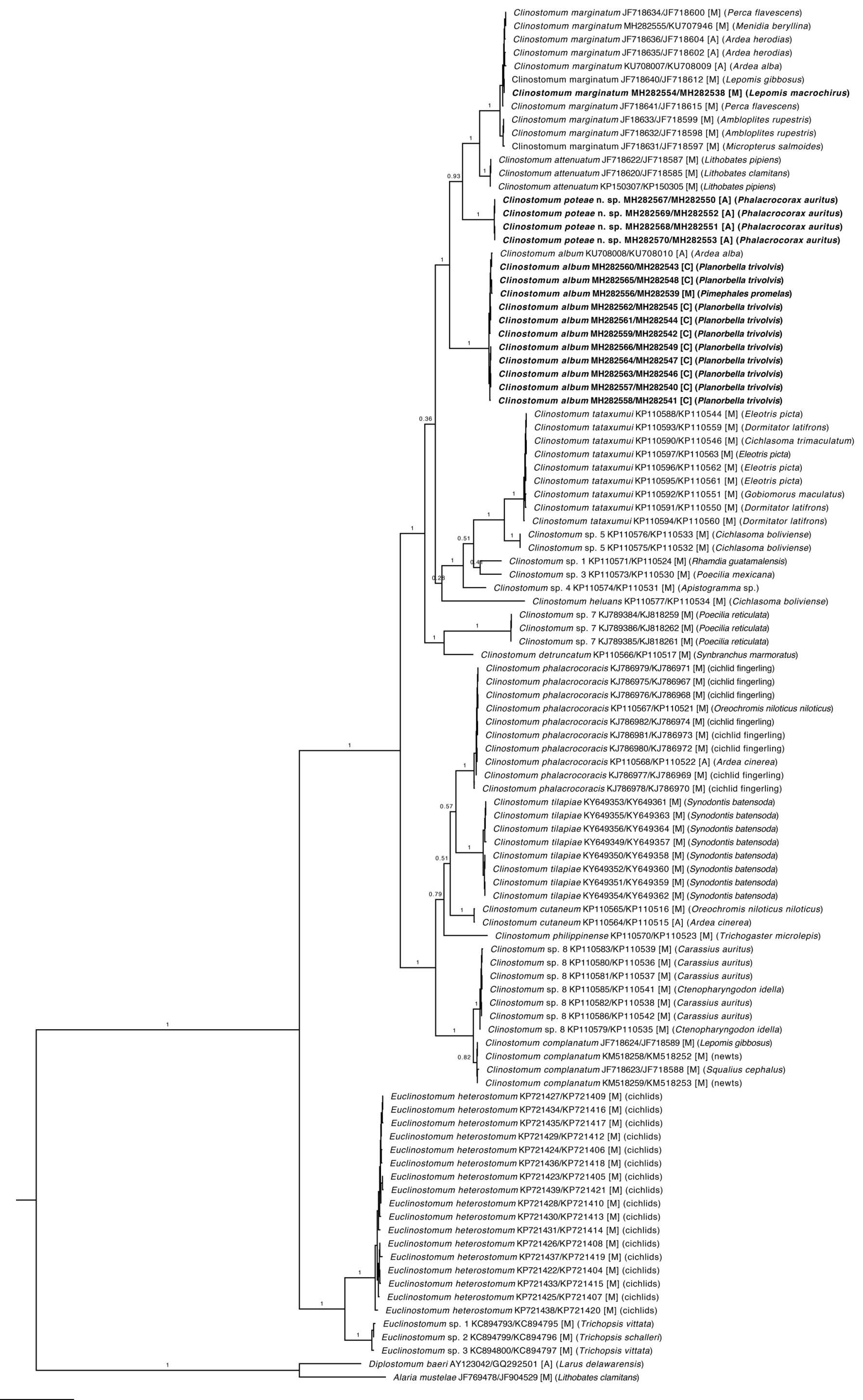

